\title{
Alterations in Gene Expression of Interferon and Tumor Necrosis Factor- $\alpha$ in Human Blood Macrophage-Like Monocytes Induced by Clinical and Standard Salmonella typhi Strains in vitro
}

\author{
Mehdi Ghanbari Sardari ${ }^{1}$, Ramak Yahya Raeyat ${ }^{1 *}$, Mohammadreza Mehrabi ${ }^{2}$ D, \\ Taghi Zahraiee Salehi $^{1}$ iD, Jalil Mehrzad Salakojani ${ }^{1}$ iD
}

1. Department of Microbiology and Immunology, Faculty of Veterinary Medicine, University of Tehran, Tehran, Iran

2. Department of laboratory Medicine, Faculty of Medicine, Borujerd Branch, Islamic Azad University, Borujerd, Iran

ABSTRACT

Background and Aim: Salmonella typhi as a human pathogen stimulates the human immune system and triggers gene expression changing its pathogenesis. Therefore, we aimed to investigate the expression levels of IFN- $\gamma$ and TNF- $\alpha$ cytokines in human blood macrophage-like monocytes in dealing with clinical and standard samples of Salmonella typhi in vivo.

Materials and Methods: In this cross-sectional descriptive study, a total of 60 stool samples from patients with gastroenteritis were cultured and biochemical tests were used to diagnose Salmonella. Also, venous blood samples were taken for peripheral blood mononuclear cell (PBMC) isolation, and PBMCs were cultured in a culture medium containing $4 \times 10^{3} \mathrm{CFU} / \mathrm{mL}$ treatments of Salmonella typhi pathogen and standard. Cytotoxicity tests were also performed to determine the concentrations. Finally, quantitative expression levels of IFN- $\gamma$ and TNF- $\alpha$ were measured and the results were analyzed by statistical tests.

Results: The results of the cytotoxicity test showed the use of Salmonella typhi concentrations for treatment in an authorized culture medium at a concentration of $4 \times 10^{3} \mathrm{CFU} / \mathrm{mL}$. In comparison to control samples, significantly increased expression levels of the TNF- $\alpha$ gene have been detected in pathogen strain and ATCC strain $(P<0.05)(P=0.0198)$. Furthermore, significantly increased expression levels of the IFN $-\gamma$ gene have been detected in the pathogen strain and ATCC strain $(P<0.05)$ in comparison to the control sample $(P=0.0001)$.

Conclusion: Increased and significant expression of IFN- $\gamma$ and TNF- $\alpha$ cytokines in the sample group treated with pathogen strain and ATCC strain indicates polarization of macrophages stimulated by Salmonella typhi in vitro.

Keywords: IFN- - , Macrophage, Salmonella typhi, TNF- $\alpha$

\begin{tabular}{l} 
Received: 2021/07/28; Accepted: 2021/11/05; Published Online: 2021/12/08 \\
\hline $\begin{array}{l}\text { Ramak Yahya Raeyat, Department of Microbiology and Immunology, Faculty of Veterinary Medicine, University of Tehran, } \\
\text { Tehran, Iran, Email: ryahya@ut.ac.ir }\end{array}$ \\
Corresponding Information: \\
\hline $\begin{array}{l}\text { Copyright } \odot \text { 2021, This is an orinal open-access article distributed under the terms of the Creative Commons Attribution-noncommercial 4.0 International License which } \\
\text { permits copy and redistribution of the material just in noncommercial usages with proper citation. }\end{array}$ \\
Use your device to scan and read the article online
\end{tabular}

Download citation: BibTeX | RIS | EndNote | Medlars | ProCite | Reference Manager | RefWorks

Send citation to: 8 Mendeley 2 zotero 1 if $\underline{\text { RefWorks }}$

\section{Introduction}

The genus Salmonella consists of rod-shaped, Gramnegative, non-spore-forming, and mostly motile intestinal bacteria with 0.7-1.5 $\mu \mathrm{m}$ in diameter and 2$5 \mu \mathrm{m}$ in length. These facultative anaerobic bacteria use organic substrates and redox reactions to obtain energy. Most Salmonella serovars produce hydrogen sulfide $\left(\mathrm{H}_{2} \mathrm{~S}\right)$ and are not able to ferment lactose, which can easily be detected by growing in an environment containing iron sulfate. There are more than 2,500 salmonella serotypes (serovar) that are classified based on cell wall antigens ( $O$ antigen), 
flagellar antigens ( $\mathrm{H}$ antigen), and surface or envelope antigens $(1,2)$.

Salmonella typhi can colonize in several human organs and is present in the lymph tissues of the small intestine, liver, spleen, and bloodstream of infected patients. Infection in animals is not known and is more common in developing countries with poor health systems and a lack of antibiotics. Typhoid fever is still common in developing countries, affecting approximately 21.5 million people each year $(3,4)$.

Salmonella is a very successful intestinal pathogen because it has different strategies to deal with the host immune system. Gastrointestinal mucosa, the first innate immune barrier, is a thick layer of mucus that covers the surface of the intestinal epithelium. Other barriers include macrophage cells, which are innate immune-specific phagocytic cells that belong to one of the cell types present in connective tissues. As mobile and fixed cells, they have important effects on the body's innate immune system (5). Macrophages are classified as mononuclear phagocytic cells, which in addition to macrophages, also include monocytes, promonocytes, and their progenitor cells. The main function of these cells is to "cleanse" the blood, lymph, and other tissues by swallowing or phagocytosis of various particles. Macrophages are taken from the bone marrow, distributed throughout the body, and have different shapes and characteristics, often depending on the tissue in which they are found, the degree of differentiation, and the age or life span of the organism in which they are found (Figure 1) (6).
Over the past few years, the analysis of changes in mRNA expression has been explored in many studies. The results showed significant mRNAs expression changes in many infections, such as Salmonellosis. These expression profiles can be used in the treatment, prevention, and diagnosis of infected patients $(7,8)$. Clinical results obtained from gene expression profiles in different studies have led to different results, which has made their certainty and reproducibility questionable. Of course, it is clear that these differences may be due to the variety of test designs, including patient types, small tissue size, and lack of control samples in the experiments. Although studies of analytical tools have led to these differences and dissatisfaction with the use of these methods, studies still give us good information (9-11).

Classically or alternatively activated macrophages are immune-affecting cells and produce large volumes of lymphokine that are associated with the expression of genes such as IFN- - , TNF- $\alpha$, and TNF- $\beta$. During the immune response to various infectious agents, M1 and M2 macrophages are activated (12). In immune regulation mechanisms, the polarization of this population forms the basis of homeostasis. One way to confirm polarization is to express the IFN $-\gamma$ and TNF $\alpha$ cytokines for phenotype M1 and TGF $\beta$ for phenotype $M 2$. The aim of this study was to investigate the effect of Salmonella typhi on the activity of human blood macrophage-like monocytes in vitro. For this purpose, the expression of IFN $-\gamma$ and TNF $-\alpha$ cytokines are used to confirm the polarization of Salmonella typhi-stimulated macrophages (13-16).

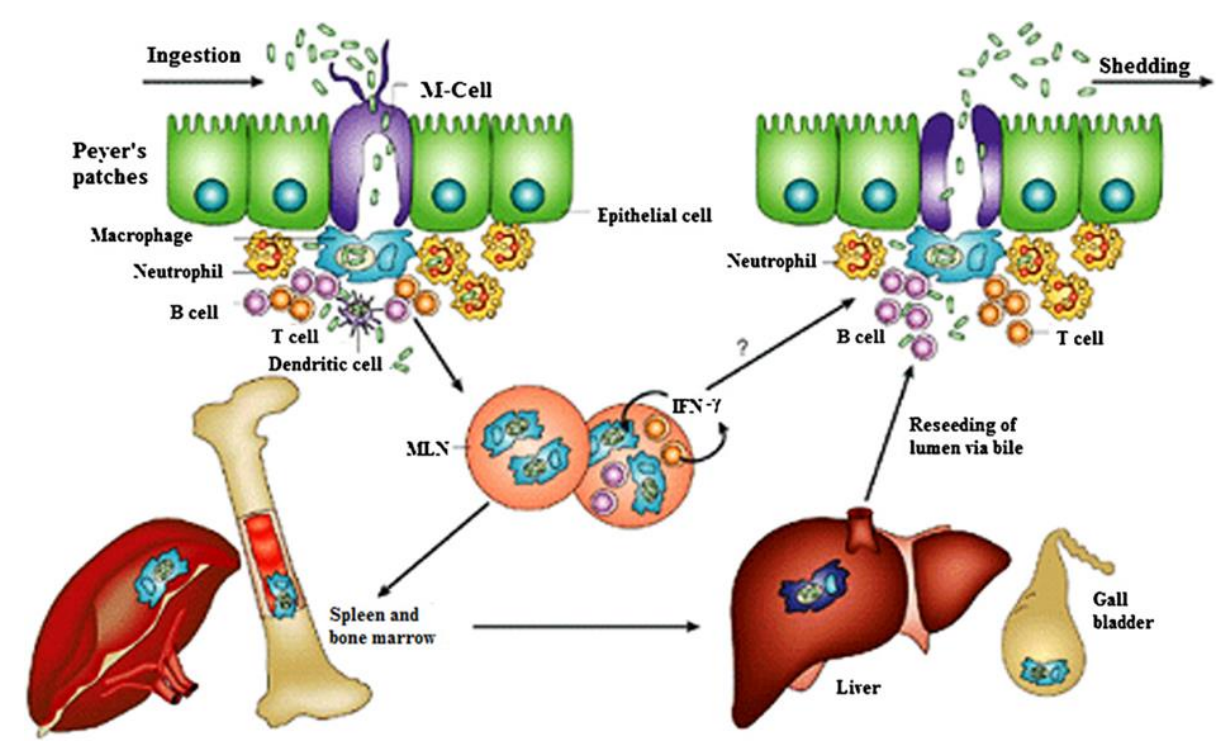

Figure 1. Schematic representation of immune cell interactions in Salmonella typhi infection (14).

\section{Material and Methods}

This cross-sectional descriptive study was performed with ethics code IR.lums.REC.1399.023 in 2021 on 60 samples of feces collected from patients with clinical signs of gastroenteritis admitted to the internal 
wards of Ayatollah Boroujerdi, Dr. Chamran, Imam Khomeini, and Kosar hospitals, Boroujerd, Iran. The volunteers were given brief explanations by a specialist and written consent was obtained. A questionnaire was completed to collect patients' demographic information. In this study, people who did not sign a written consent, who had taken antibiotics before sampling, and also had a suppressed immune system were excluded from the study.

\section{Sample Collection}

Stool samples were collected in a clean, widemouthed plastic container with a tight, leak-free lid. The container was free of preservatives, detergents, metal ions, or toilet paper. At least one gram of stool with normal consistency (about the size of a hazelnut) or $5 \mathrm{~mL}$ of diarrhea stool was used for culture. Stool samples were taken fresh and cultured up to 2 hours after sampling.

Isolation and Identification of Salmonella sp.

To identify Salmonella sp., biochemical tests, including oxidase, nitrate, glucose fermentation, and gas production, TSI $(\mathrm{H} 2 \mathrm{~S}+)$, lactose-sucrose-ONPG, IMViCC (- + -) were performed. The Salmonella typhi ATCC14028 was used as a control purchased from Iran Scientific-Industrial Research Center (17).

\section{Isolation of Peripheral Blood Mononuclear Cells (PBMCs)}

First, $15 \mathrm{cc}$ of fresh heparin-containing venous blood was obtained from healthy volunteers. Then, under sterile conditions, an equal amount of phosphatebuffered saline (PBS) was added. Five $\mathrm{mL}$ of Ficoll (Inno-train, Germany) was added to $5 \mathrm{~mL}$ of blood mixed with PBS in a 15-cc tube. Blood was slowly added, eventually forming two separate phases. It was then centrifuged at $2000 \mathrm{rpm}$ for 30 minutes. After that, a white, cloudy halo formed in the middle, which are PBMC cells. Platelets and plasma were elevated, and red blood cells and granulocytes were precipitated. Finally, PBMCs were gently removed with a Pasteur pipette, and cell survival percentage was counted after staining with trypan blue. PBMCs were then cultured in a flask containing RPMI 1640 (Roswell Park Memorial Institute) (Gibco, USA), FBS 10\% (Fetal Bovine Serum) (Gibco, USA), and Pen-Strep 1\%. The flask was incubated at $37^{\circ} \mathrm{C}$ and $5 \% \mathrm{CO}_{2}$. Monocytic populations were separated from floating cells in a complete cell culture medium by the adhesion technique. Mononuclear cells were attached to the culture medium and transformed into macrophagelike monocyte cells, which confirmed the morphology of macrophage-like monocytes using a contrast phase microscope. After 3 days, the culture medium was changed, and the cells were passaged in three flasks separately, and each flask was treated (18).

It should be noted that the concentration of stimuli was previously determined by a cytotoxicity test using trypan blue. The results showed the use of Salmonella typhi concentrations for treatment in the authorized culture medium at a concentration of $4 \times 10^{3} \mathrm{cfu} / \mathrm{mL}$. Under completely sterile conditions, macrophage-like monocytes attached to the culture medium were separated from the flask by a scraper. After washing with serum-free medium (2000 rpm for five minutes), cell sediment was used to study gene expression in the next step.

\section{RNA Extraction with TRIzol}

TRIzol 'm Reagent Cat Numbers 155960 (Thermo Fisher Scientific, Inc.) was used to extract RNA from the flask. In addition, RNase / DNase free microtubes, filtered tips, and nuclease-free water were used to prevent DNA contamination. In addition, RNase enzyme (Yekta Tajhiz, Iran) was used to remove extracted RNA.

\section{cDNA Syntheses}

Smobio (Taiwan) was used for cDNA synthesis according to the kit instructions. 500 ng of RNA was removed from each sample and reached a volume of $4 \mu \mathrm{L}$ with water. Then $0.5 \mu \mathrm{L}$ of dNTPs and $0.5 \mu \mathrm{L}$ of Oligo dt and Random hexamer primers were added and incubated at $70^{\circ} \mathrm{C}$ for 5 minutes in a thermocycler device. Then $2 \mu \mathrm{L}$ of DTT, $2 \mu \mathrm{L}$ of DEPC water, $0.5 \mu \mathrm{L}$ of RNAse inhibitor and finally $0.5 \mu \mathrm{L}$ of RT enzyme were added to each microtube. All microtubes were incubated in a thermocycler device for 50 minutes at $45^{\circ} \mathrm{C}$.

Expression of TNF- $\alpha$, IFN- $\gamma$ using Real-Time PCR For real-time PCR, Amplicon master mix and SYBR Green were used, which contains fluorescence and, after connecting to double-stranded DNA, emits fluorescent light. Finally, this light is measured by a Real-Time PCR device. In these reactions, the prepared cDNA was used as the template. GAPDH primer was used as an internal control. The sequence of primers used is shown in Table 1.

\section{Statistical Analysis}

All data obtained from Real-Time PCR were analyzed using Excel and GraphPad Prism software. Finally, the results were analyzed using the one-way ANOVA test, and statistical results less than 0.05 were considered significant. 
Table 1. The sequence of primers for Real-time PCR (37)

\begin{tabular}{|c|c|c|}
\hline Primer & Sequence & Molecular weight \\
\hline IFN- $\nu \mathrm{F}$ & TTGGGTTCTCTTGGCTGTTA & \multirow{2}{*}{$151 b p$} \\
\hline IFN- $\boldsymbol{\nu}$ R & TTCTGTCAСTСТССТССТССА & \\
\hline TNF- $\alpha \mathrm{F}$ & TTGGGTTCTCTTGGCTGTTA & \multirow{2}{*}{$251 b p$} \\
\hline TNF- $\alpha$ R & TTCTGTCAСTCTССTССТССА & \\
\hline GAPDH-F & TGCTGTCTCCCTGTTTGATGTATCT & \multirow{2}{*}{86 bp } \\
\hline GAPDH-R & TCTCTGCTCCCCACCTCTAAGT & \\
\hline
\end{tabular}

\section{Results}

\section{Sample Collection Results}

Sixty patients with clinical signs of gastroenteritis, including 39 men and 21 women with a mean age of
$55 \pm 4$, were studied. Salmonella spp. was isolated from these 60 collected specimens, 3 of which were Salmonella typhi.

Table 2. Results of biochemical tests of fecal samples

\begin{tabular}{ccccccccccccc} 
Organism & $\mathrm{kIA}$ & $\mathrm{H}_{2} \mathrm{~S}$ & Gas & $\mathrm{MR}$ & $\mathrm{VP}$ & citrate & $\mathrm{LDC}$ & Urease & Arabinose & $\begin{array}{c}\text { Ornitin } \\
\text { decarboxylase }\end{array}$ & Rhamnose & Trehalose \\
$\begin{array}{c}\text { Genus: } \\
\text { Salmonella } \\
\text { Typhi }\end{array}$ & $A L K / A$ & + & - & + & - & - & + & - & - & - & - & + \\
\hline
\end{tabular}

\section{Results of Specificity and Sensitivity of Primers}

In order to design the primers, the mRNA sequence was extracted from the NCBI databases; the desired regions were designed for the target genes by Gene runner. Finally, the regions were specifically approved in the BLAST database.

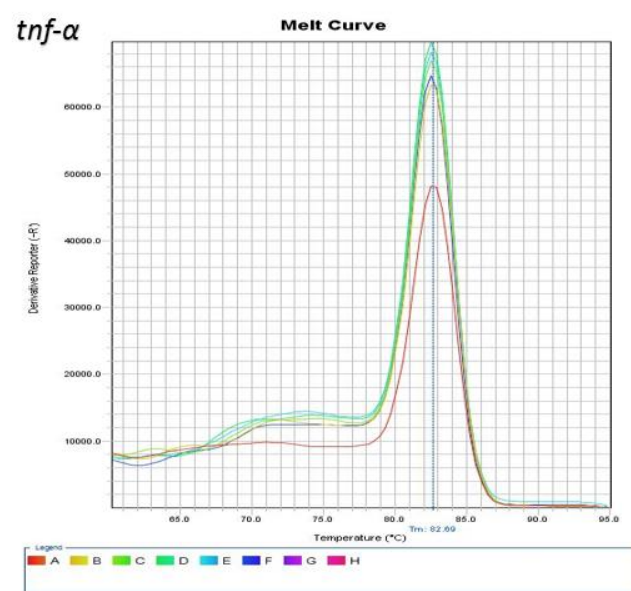

Investigation of the Specific Amplification of Realtime PCR Products

The final products obtained from Real-time PCR were loaded on $5 \%$ agarose gel and electrophoresed to ensure the amplification of specific fragments of each gene and the absence of non-specific products and dimer primers. In addition, the melting curve was used (Figure 2).

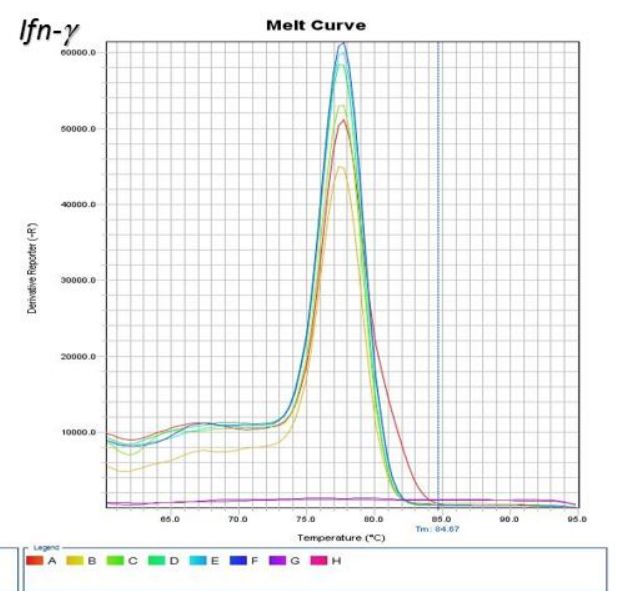

Figure 2. Melting curve of studied genes such as TNF- $\alpha$ and IFN- $\gamma$, which indicates the specificity of their amplification.

\section{Results of TNF- $\alpha$ Gene Expression}

Quantitative expression of TNF- $\alpha$ gene in 60 cell culture media grown in medium containing
Salmonella typhi or ATCC14028 standard strain with a concentration of $4 \times 10^{3} \mathrm{cfu} / \mathrm{mL}$ was measured by RealTime PCR after RNA extraction and cDNA synthesis. 
The results showed that the relative changes in TNF- $\alpha$ gene expression in PBMCs treated with pathogen and ATCC strains both had a significant increase compared to the control sample ( $p$ : 0198). Also, the one-way ANOVA test and Tukey's multiple comparison tests were used for the group's comparison (Table 3). The increase in TNF- $\alpha$ gene expression in the pathogen group was statistically significant than in the control group.

Table 3. Comparison of TNF- $\alpha$ gene expression in target groups

\begin{tabular}{cccc}
\hline Tukey's multiple comparisons test & Mean Diff. & $\mathbf{9 5 \%}$ Cl of diff. & Significant? \\
\hline Control vs. ATCC & -0.4589 & -1.948 to 1.030 & No \\
\hline Control vs. Pathogen & -1.875 & -3.364 to -0.3861 & Yes \\
\hline ATCC vs. Pathogen & -1.416 & -2.905 to 0.07280 & No \\
\hline
\end{tabular}

Quantitative results of changes in TNF- $\alpha$ gene expression in control samples and in PBMCs treated with the pathogen and ATCC14028 strains are shown in Figure 3 , and the multiplication of this gene (folds) in each sample is shown in Table 4.

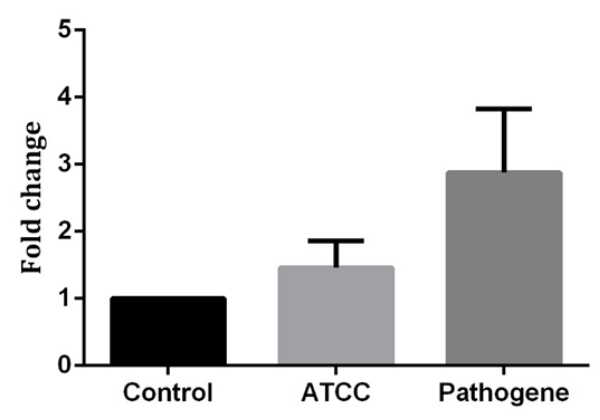

Figure 3. Changes in TNF- $\alpha$ gene expression in control, ATCC, and pathogen samples
Table 4. Expression TNF- $\alpha$ gene

\begin{tabular}{cc|} 
Sample Type & Fold Change \\
\hline control & 1 \\
ATTC & 1.45 \\
\hline Pathogen & 2.87 \\
\hline
\end{tabular}

\section{Results of IFN- $\boldsymbol{\nu}$ Gene Expression}

Quantitative expression of IFN- $\gamma$ gene in the control group, samples treated with the pathogen and ATCC1609 strains was measured by Real-time PCR after RNA extraction and cDNA synthesis. The results showed that the relative changes in IFN- $\gamma$ gene expression in PBMCs treated with the pathogen and ATCC14028 strains both had a significant increase compared to the control sample $(P=0.001)$ (Figure 4). Also, using the One-way ANOVA test and Tukey's multiple comparison test, the groups were compared with each other, and the results are shown in Table 5. A statistically significant increase in IFN- $\gamma$ gene expression in the pathogen group was observed than the control and ATCC 14028 groups.

Table 5. Comparison of IFN- $\gamma$ gene expression in control, ATCC 14028 and pathogen

\begin{tabular}{|c|c|c|c|}
\hline Tukey's multiple comparisons test & Mean Diff. & $95 \% \mathrm{Cl}$ of diff. & Significant? \\
\hline Control vs. ATCC 14028 & -0.1777 & -1.103 to 0.7475 & No \\
\hline Control vs. pathogen & -2.010 & -2.935 to -1.084 & Yes \\
\hline ATCC vs. pathogen & -1.832 & -2.757 to -0.9067 & Yes \\
\hline
\end{tabular}

Quantitative results of changes in IFN- $p$ gene expression in control samples and in PBMCs treated with the pathogen and ATCC 14028 strains are shown in Figure 4, and the multiplication of this gene (folds) in each sample is shown in Table 6.
Table 6. Multiplication table of INF- $\gamma$ gene expression

\begin{tabular}{cc} 
Sample Type & Fold Change \\
\hline Control & 1 \\
ATCC 14028 & 1.17 \\
\hline Pathogen & 3 \\
\hline
\end{tabular}




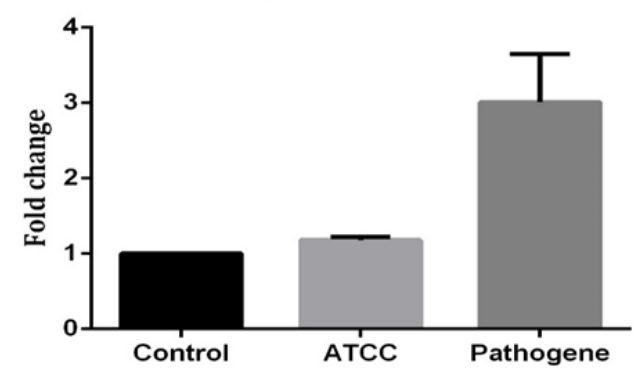

Figure 4. Changes in IFN- $-\gamma$ gene expression in control, ATCC, and pathogen groups

\section{Discussion}

Studies have shown that disease progression is associated with changes in expression at the genome level. Although the molecular mechanism involved due to these genetic changes is not yet fully understood, researchers have reported the activation of several genes in different cellular pathways. The range of changes in the expression of these genes and the pathways involved in bacterial infection is very diverse and wide. In other words, disease development is a very complex process associated with the abnormal expression of several genes. Therefore, changes in gene expression can be used as a biomarker in the diagnosis of disease $(19,20)$. Therefore, these changes can be used to diagnose Salmonellosis and to study the mechanism of action of the immune system and bacteria against each other.

S. typhi pathogenesis, like other Salmonella, is complex and multifactorial. This microorganism causes a wide and diverse set of infections (21). S. typhi pathogenicity depends on its ability to attack cells and form a protective lipopolysaccharide (LPS), the presence of $\mathrm{Vi}$ antigen, and the production of invasin (inv genes), a protein that attacks non-phagocytic cells; where bacteria can survive and multiply intracellularly $(22,23)$. These factors in the host cause immune system reactions.

In the 1990s, IL-4 was discovered to have different effects on macrophage gene expression compared to IFN- $\gamma$ and LPS. In contrast to classical macrophage activation by IFN- $\gamma$, IL-4-induced macrophage gene expression was described as "alternative activation". A few years later, in 2000, Mills et al. proposed a new classification of macrophages as M1 or M2. These terms derive from the observation of macrophage arginine metabolism in mice by working on $\mathrm{T}$ helper type 1 (Th1) and T helper type 2 (Th2) $(24,25)$.

Th1 that produces more IFN- $\gamma$ showed macrophage activation in which nitric oxide (NO) is produced from arginine, whereas ornithine is produced from Th2, which produces IL-4 and TGF $\beta 1$. This finding led to a consensus in the scientific community that M1 macrophages (classical activators) exhibit inflammatory functions, while M2 macrophages (alternative activators) exhibit anti-inflammatory functions (26). In 2004, Mantowani et al. further subdivided M2 macrophages into subgroups $M 2 a, M 2 b, M 2 c$, and $\mathrm{M} 2 \mathrm{~d}$ based on stimuli applied and the resulting transcriptional changes. Classification of $M 1 / M 2$ macrophages is currently considered a fairly simple method that does not adequately describe the population spectrum of macrophages (27).

For example, identifying tumor-associated macrophages (TAMs), which do not fit well into the M1 or M2 macrophage criteria, complicates the system. In addition, macrophages expressing $T$ cell and CD169 receptors have been identified. The phenotype of macrophage subsets $\mathrm{M} 1$ and $\mathrm{M} 2$ and the function of macrophages derived from monocyte precursors are differentiated depending on the local tissue environment (28). They respond to environmental signals in tissues such as damaged cells, activated lymphocytes, or microbial products to distinguish distinct functional phenotypes. The M1 macrophage phenotype is characterized by the production of high levels of proinflammatory cytokines, the ability to resist pathogens, strong antimicrobial properties, the production of highly reactive nitrogen and oxygen mediators, and the enhancement of Th1 responses. In contrast, M2 macrophages are characterized by their efficient control of parasitic infection, tissue regeneration, immune regulation, tumor promotion, and efficient phagocytic activity (25). Therefore, in this study, the expression of genes related to cytokines TNF- $\alpha$ and IFN- $\gamma$ was prioritized.

LPS, IFN- - , and granulocyte-macrophage colonystimulating factor (GM-CSF) polarize macrophages toward the M1 phenotype, which secretes large amounts of cytokines such as IL-1- $\beta$, TNF, IL-12, IL- 18, and IL-23. This helps to properly carry out the inflammatory responses of Th1 and Th17 cells specific for antigens (29). Typically, M1 macrophages stimulate high levels of class II tissue adaptation complexes, CD68 markers, and CD80 and CD86 molecules. M1 macrophages have also been shown to regulate SOCS3 expression and activate NOS2 to produce NO from Larginine. In the context of disease, M1 macrophages are involved in initiating and maintaining inflammation, so they can be harmful to health (30).

Macrophages $\mathrm{M} 1$ and $\mathrm{M} 2$ have different chemokine and chemokine receptor profiles, with M1 secreting Th1-absorbing chemokines such as C1 in CXCL9 and CXCL10, and M2 secreting CCL17, CCL22, and CCL24. Recently, it has been shown that macrophages are able to repolarize from $\mathrm{M} 2$ to $\mathrm{M} 1$ in vitro, and reverse polarization depends on the chemokine environment. 
Signaling molecules are involved in M1 / M2 polarization. A network of transcription factors and post-transcriptional regulators are involved in $\mathrm{M} 1$ / M2 polarization (Figure 5). Interferon regulatory factor (IRF), STAT, and SOCS are all involved in the deviation of macrophage function towards the M1 or M2 phenotype $(31,32)$. IRF / STAT pathways activated by IFNs and TLR signaling polarize macrophages via STAT1 to M1 activation mode (33). M1 macrophages have been shown to regulate IRF5, which is involved in M1 polarization for M1 polarization and the whole STAT1-alpha / beta in an independent manner via MyD88 (27).

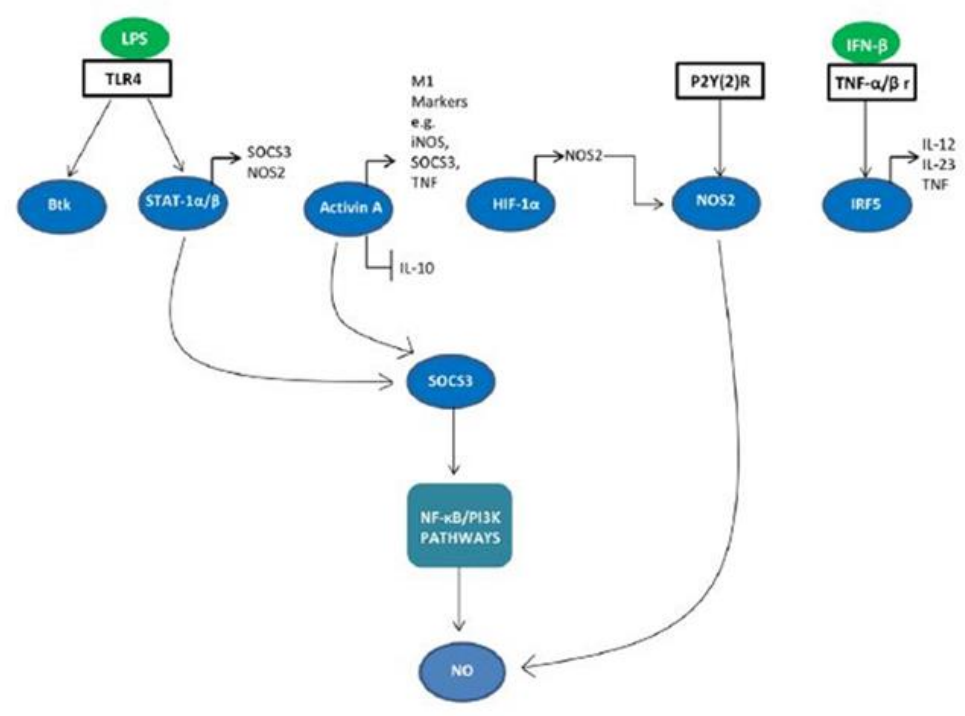

Figure 5. Signaling molecules involved in M1 polarization

In the present study, the gene expression of IFN $-\gamma$ and TNF- $\alpha$ cytokines was evaluated to confirm the polarization of Salmonella typhi-stimulated macrophages in vitro in two groups of clinical and standard strains of $S$. typhi. The results of gene expression analysis showed both genes have increased in expression in clinical and standard strains of $S$. typhi compared to the control group. This increase in expression was significant in the clinical strain of $S$. typhi, which was higher than the standard strain.

In a study conducted by Ami Febriza in 2020 to measure TNF- $\alpha$ on blood samples of $S$. typhi-infected mice using the ELISA method, it was found that TNF- $\alpha$ levels in infected samples increased and treatment of mice with antibiotics leads to its reduction (34). In addition, IFN- $\gamma$ has been shown to play a vital role in resistance to $S$. typhi infection by increasing the antibacterial activity of macrophages. It has also recently been shown that IFN- $\gamma$ and TNF- $\alpha$ activate the JAK / STAT1 / IRF pathway in mice infected with COVID19 infection, leading to lethal cytokine shock, and therefore death from COVID-19 can be prevented by using neutralizing antibodies against them (14). In a study conducted in 2019, the relationship between the profiles of IFN- $\gamma$ and TNF- $\alpha$-producing cells and liver and kidney damage in hepatitis $B$ virus infection was found (35). As a result, according to the studies, changes in the expression of IFN- $\gamma$ and TNF- $\alpha$ cyto-kines can be used to identify S. typhi-related infections (36).

However, it should be noted that the present study could not investigate all the molecular aspects of polarization of macrophages and cytokines in the study and it is suggested that for better understanding of molecular pathways, more experiments be perfor-med.

\section{Conclusion}

The increased expression of IFN- $\gamma$ and TNF- $\alpha$ in both clinical and standard strains of $S$. typhi compared to the control group confirms their role in macrophage polarization. Therefore, we can use their expression changes as a molecular biomarker in the diagnosis of Salmonella-related infections.

\section{Acknowledgment}

The authors would like to thank all the people who helped in the various stages of this research. The Department of Microbiology and Immunology, Faculty of Veterinary Medicine, University of Tehran is also commended for providing the location and experimental materials, as well as the Department of Laboratory Sciences of the Islamic Azad University, Boroujerd Branch. 


\section{Funding}

This article is taken from the PhD thesis in bacteriology, which was done in collaboration with the University of Tehran Research Council, and the relevant resources were provided by the ViceChancellor for Research, University of Tehran.

\section{Conflict of Interest}

There is no conflict of interest among the authors.

\section{References}

1. Coburn B, Grassl GA, Finlay BB. Salmonella, the host and disease: a brief review. Immunol Cell Biol. 2007; 85(2):112-8. [DOI:10.1038/sj.icb.7100007] [PMID]

2. Herrero-Fresno A, Olsen JE. Salmonella typhimurium metabolism affects virulence in the host - A minireview. Food Microbiol. 2018;71:98-110. [DOI:10.1016/j.fm.2017.04.016] [PMID]

3. Ramachandran G, Panda A, Higginson EE, Ateh E, Lipsky MM, Sen $S$, et al. Virulence of invasive Salmonella typhimurium ST313 in animal models of infection. PLoS Negl Trop Dis. 2017;11(8):e0005697. [DOI:10.1371/iournal.pntd.0005697] [PMID] [PMCID]

4. Sun H, Wan Y, Du P, Bai L. The Epidemiology of Monophasic Salmonella typhimurium. Foodborne Pathog Dis. 2020;17(2):87-97. [DOI:10.1089/fpd.2019.2676] [PMID]

5. Broz $\mathrm{P}$, Ohlson $\mathrm{MB}$, Monack DM. Innate immune response to Salmonella typhimurium, a model enteric pathogen. Gut Microbes. 2012;3(2):62-70. [DOI:10.4161/gmic.19141] [PMID] [PMCID]

6. Linehan SA, Holden DW. The interplay between Salmonella typhimurium and its macrophage hostwhat can it teach us about innate immunity? Immunol lett. 2003;85(2):183-92. [DOI:10.1016/S01652478(02)00227-4]

7. Bazrgari N, Garoosi GA, Dadar M. Genetic Diversity and Phylogenetic Relationship of Clinical Isolates of Brucella melitensis Based on Gene Polymorphism of $\beta$ Subunit of RNA Polymerase (rpoB) Gene in Iran. Iran J Med Microbiol. 2020;14(5):425-40.

[DOI:10.30699/ijmm.14.5.425]

8. Rosenberger $\mathrm{CM}$, Scott MG, Gold MR, Hancock RE, Finlay BB. Salmonella typhimurium infection and lipopolysaccharide stimulation induce similar changes in macrophage gene expression. J Immunol. 2000;164(11):5894-904.

[DOI:10.4049/iimmunol.164.11.5894] [PMID]

9. Khezri M, Rezaei M, Mohabbati Mobarez A. Detection of viable but non-culturable state of Escherichia coli 0157: H7 using reverse transcription PCR. Iran J Med Microbiol. 2019;12(6):390-8.

[DOI:10.30699/ijmm.12.6.390]

10. Monson MS, Bearson BL, Sylte MJ, Looft T, Lamont SJ, Bearson SMD. Transcriptional response of blood leukocytes from turkeys challenged with Salmonella enterica serovar Typhimurium UK1. Vet Immunol Immunopathol. 2021;232:110181.

[DOI:10.1016/j.vetimm.2020.110181] [PMID]

11. Sheikh A, Charles RC, Sharmeen N, Rollins SM, Harris $J B$, Bhuiyan MS, et al. In vivo expression of Salmonella enterica serotype Typhi genes in the blood of patients with typhoid fever in Bangladesh. PLoS Negl Trop Dis. 2011;5(12):e1419.

[DOI:10.1371/journal.pntd.0001419] [PMID] [PMCID]

12. Bardi GT, Smith MA, Hood JL. Melanoma exosomes promote mixed $\mathrm{M} 1$ and $\mathrm{M} 2$ macrophage polarization. Cytokine. 2018;105:63-72. [DOI:10.1016/j.cyto.2018.02.002] [PMID] [PMCID]

13. Atri C, Guerfali FZ, Laouini D. Role of Human Macrophage Polarization in Inflammation during Infectious Diseases. Int J Mol Sci. 2018;19(6):1801. [DOI:10.3390/ijms19061801] [PMID] [PMCID]

14. Kaur J, Jain SK. Role of antigens and virulence factors of Salmonella enterica serovar Typhi in its pathogenesis. Microbiol Res. 2012;167(4):199-210. [DOI:10.1016/j.micres.2011.08.001] [PMID]

15. Kim JE, Phan TX, Nguyen VH, Dinh-Vu HV, Zheng JH, Yun $M$, et al. Salmonella typhimurium Suppresses Tumor Growth via the Pro-Inflammatory Cytokine Interleukin-1beta. Theragnostic. 2015;5(12):1328-42. [DOI:10.7150/thno.11432] [PMID] [PMCID]

16. Sheppe AEF, Kummari E, Walker A, Richards A, Hui WW, Lee JH, et al. PGE2 Augments Inflammasome Activation and M1 Polarization in Macrophages Infected with Salmonella typhimurium and Yersinia enterocolitica. Front Microbiol. 2018;9:2447. [DOI:10.3389/fmicb.2018.02447] [PMID] [PMCID]

17. Hojati P. Isolation and identification of Salmonella poultry ERic-PCR and serological methods (Doctoral dissertation, Dissertation of Poultry Veterinary. Tehran. Science and Research Azad University. 1997. [in Persian]

18. Panda SK, Ravindran B. Isolation of human PBMCs. Bioprotocol. 2013;3(3):e323-e. [DOI:10.21769/BioProtoc.323]

19. Emilsson V, Thorleifsson G, Zhang B, Leonardson AS, Zink F, Zhu J, et al. Genetics of gene expression and its effect on disease. Nature. 2008;452(7186):423-8. [DOI:10.1038/nature06758] [PMID]

20. Schadt EE, Lamb J, Yang X, Zhu J, Edwards S, GuhaThakurta D, et al. An integrative genomics approach to infer causal associations between gene expression and disease. Nat Genet. 2005;37(7):710-7. [DOI:10.1038/ng1589] [PMID] [PMCID]

21. Dos Santos AMP, Ferrari RG, Conte-Junior CA. Virulence Factors in Salmonella typhimurium: The Sagacity of a Bacterium. Curr Microbiol. 2019;76 (6):762-73. [DOI:10.1007/s00284-018-1510-4] [PMID]

22. Furter M, Sellin ME, Hansson GC, Hardt WD. Mucus Architecture and Near-Surface Swimming Affect Distinct Salmonella Typhimurium Infection Patterns along the Murine Intestinal Tract. Cell Rep. 
2019;27(9):2665-78 e3.

[DOI:10.1016/i.celrep.2019.04.106] [PMID] [PMCID]

23. Herman R, Bennett-Ness C, Maqbool A, Afzal A, Leech A, Thomas GH. The Salmonella enterica serovar Typhimurium virulence factor STM3169 is a hexuronic acid binding protein component of a TRAP transporter. Microbiology. 2020;166(10):981. [DOI:10.1099/mic.0.000967] [PMID] [PMCID]

24. Muraille $\mathrm{E}$, Leo $\mathrm{O}$, Moser M. TH1/TH2 paradigm extended: macrophage polarization as an unappreciated pathogen-driven escape mechanism? Front immunol. 2014;5:603.

[DOI:10.3389/fimmu.2014.00603]

25. Murray PJ, Wynn TA. Obstacles and opportunities for understanding macrophage polarization. J Leukoc Biol. 2011;89(4):557-63. [DOI:10.1189/jlb.0710409] [PMID] [PMCID]

26. Saqib U, Sarkar S, Suk K, Mohammad O, Baig MS, Savai R. Phytochemicals as modulators of M1-M2 macrophages in inflammation. Oncotarget. 2018;9 (25):17937. [DOI:10.18632/oncotarget.24788] [PMID] [PMCID]

27. Orecchioni $M$, Ghosheh $Y$, Pramod $A B$, Ley $K$. Macrophage Polarization: Different Gene Signatures in M1(LPS+) vs. Classically and M2(LPS-) vs. Alternatively Activated Macrophages. Front immunol. 2019;10:1084. [DOl:10.3389/fimmu.2019.01084] [PMID] [PMCID]

28. Weyand CM, Zeisbrich M, Goronzy JJ. Metabolic signatures of T-cells and macrophages in rheumatoid arthritis. Curr Opin Immunol. 2017;46:112-20. [DOI:10.1016/i.coi.2017.04.010] [PMID] [PMCID]

29. Liu L, Guo H, Song A, Huang J, Zhang Y, Jin S, et al. Progranulin inhibits LPS-induced macrophage M1 polarization via NF-small $k a$, CyrillicB and MAPK pathways. BMC Immunol. 2020;21(1):32. [DOI:10.1186/s12865-020-00355-y] [PMID] [PMCID]

30. Rath M, Muller I, Kropf P, Closs El, Munder M. Metabolism via Arginase or Nitric Oxide Synthase: Two Competing Arginine Pathways in Macrophages. Front immunol. 2014;5:532.

[DOI:10.3389/fimmu.2014.00532] [PMID] [PMCID]
31. Jimenez-Garcia L, Higueras MA, Herranz $S$, HernandezLopez $\mathrm{M}$, Luque A, de Las Heras B, et al. A hispanolonederived diterpenoid inhibits M2-Macrophage polarization in vitro via JAK/STAT and attenuates chitin induced inflammation in vivo. Biochem Pharmacol. 2018;154:373-83. [DOI:10.1016/j.bcp.2018.06.002] [PMID]

32. Qin H, Holdbrooks AT, Liu Y, Reynolds SL, Yanagisawa $\mathrm{LL}$, Benveniste EN. SOCS3 deficiency promotes M1 macrophage polarization and inflammation. J Immunol. 2012;189(7):3439-48.

[DOI:10.4049/jimmunol.1201168] [PMID] [PMCID]

33. Platanitis E, Decker T. Regulatory Networks Involving STATs, IRFs, and NFkappaB in Inflammation. Front immunol. 2018;9:2542.

[DOI:10.3389/fimmu.2018.02542] [PMID] [PMCID]

34. Febriza A, Natzir R, Hatta M, As' ad S, Kaelan C, Kasim VN, et al. The Role of IL-6, TNF- $\alpha$, and VDR in Inhibiting the Growth of Study. Open Microbiol. 2020;14(1). [DOI:10.2174/1874285802014010065]

35. Wang $\mathrm{H}$, Luo $\mathrm{H}$, Wan X, Fu X, Mao $Q$, Xiang X, et al. TNF$\alpha /$ IFN- $\gamma$ profile of HBV-specific CD4 T cells is associated with liver damage and viral clearance in chronic HBV infection. Journal of hepatology. 2020;72(1):45-56. [DOI:10.1016/j.jhep.2019.08.024] [PMID]

36. Hu JL, Yu H, Kulkarni RR, Sharif S, Cui SW, Xie MY, et al. Modulation of cytokine gene expression by selected Lactobacillus isolates in the ileum, caecal tonsils and spleen of Salmonella-challenged broilers. Avian Pathol. 2015;44(6):463-9. [DOI:10.1080/03079457.2015.1086725] [PMID]

37. Gao J, Wu Y, Su Z, Amoah Barnie P, Jiao Z, Bie Q, et al.. Primers used in real-time PCR. [Internet]. PLOS ONE; 2015 [cited 2021Dec22].. Available from: https://plos.figshare.com/articles/dataset/ Primers used in real time PCR /1148102/1 


$$
\begin{aligned}
& \text { مجله ميكروبشناسى يزشكى ايران } \\
& \text { سال 14 ـ شماره \& _ آذر و دى +. }
\end{aligned}
$$

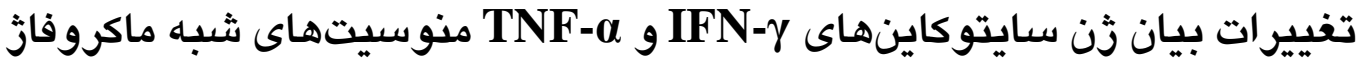 \\ خون انسان در مجاورت نمونههاى بالينى و استاندارد سالمونلا تيفى در شرايط برون تن}

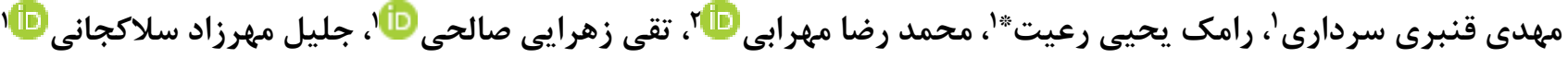

$$
\begin{aligned}
& \text { ' . كروه ميكروبشناسى و ايمنى شناسى، دانشكده داميزشكى دانشكاه تهران، تهران، ايران }
\end{aligned}
$$

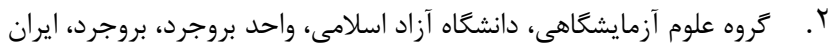

\section{جـكيده}

زمينه و اهداف: سالمونلا تيفى يك ياتورن انسانى است كه موجب تحريك سيستم ايمنى انسان و ايجاد تغييرات در سطح

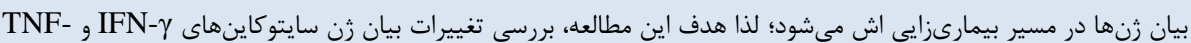

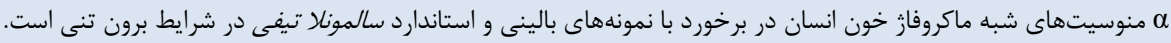

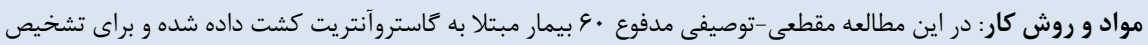

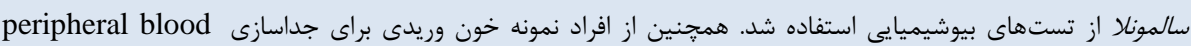

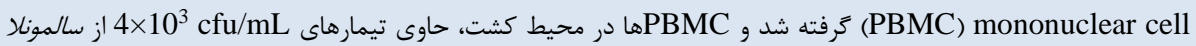

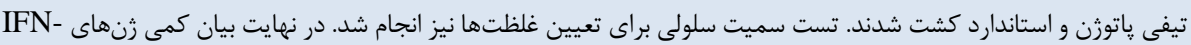
TNF- $\alpha$, $\gamma$

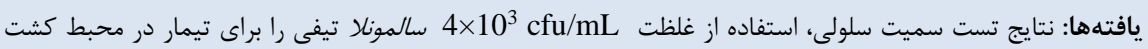

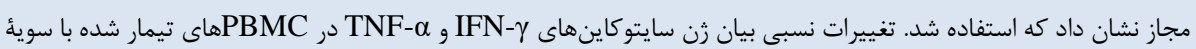
ياتوزن و سويأ

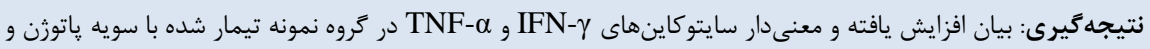

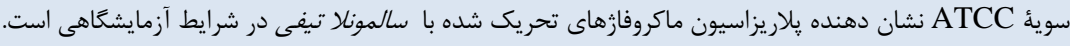
كليد وازهها: سالمونلا تيفى،

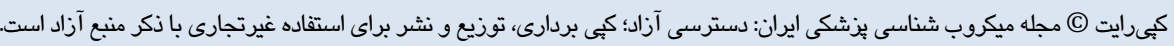

اطلاعات مقاله

تاريخجهُ مقاله

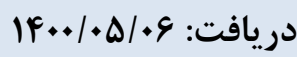

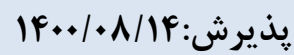

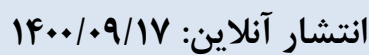

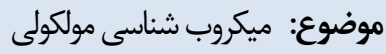

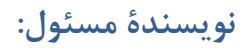

رامك يحيى رعيت

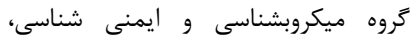

دانشكده داميزشكى دانشعاه تهران، تهران،

ايران

ايميل:

ryahya@ut.ac.ir

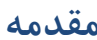

سالمونلا تيفى يك ياتوزن با قابليت كلونيزه شدن در گند ارگًان انسان است كه در بافتهاى لنفاوى روده كوجى، كبد، طحال و جريان خون انسانهاى آلوده حضور دارد. آلودگى در حيوانات شناخته شده نيست و بيشتر در كشورهاى در حال توسعه با سيستم بهداشتى ضعيف و كمبود آنتىبيوتيك ديده مىشود. تب تيفوئيد هنوز در كشورهاى در حال توسعه رايج است، جايى كه هر

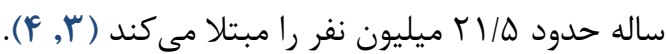
سالمونلا يك ياتوزن روده بسيار موفق است، زيرا براى مقابله با بيشتر عوامل و مكانيسم هاى سيستم ايمنى بدن كه در مراحل مختلف بيمارى توسط ميزبان استفاده مىشود، استراتزىهايى ايجاد كرده است. مكانيسمهاى ايمنى ذاتى مخاط گوارشى يكى از
جنس سالمونلا شامل باكترىهاى رودهاى ميلهاى شكل، گرم

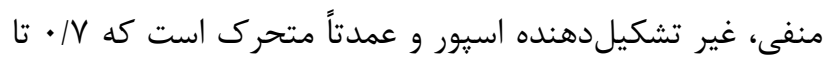
ه/ ميكرون قطر و r تا ه ميكرون طول دارند. اين باكترىها بىهوازى هاى اختيارى هستند كه از بسترهاى آلى و واكنشهاى كاهش اكسيداسيون براى انرزى استفاده مى كنند. اكثر سروواوهاى سالمونلا سولفيد هيدروزن توليد مى كنند و قادر به تخمير لاكتوز نيستند و با رشد در محيط حاوى سولفات آهن به راحتى قابل

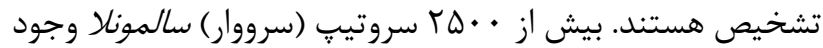

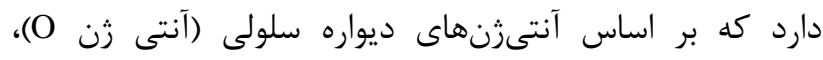

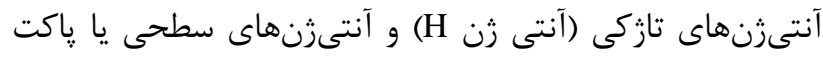

دستهبندى مىشوند (ا, ؟). 
نتايج كلينيكى حاصل از يروفايل بيان زنى در مطالعات

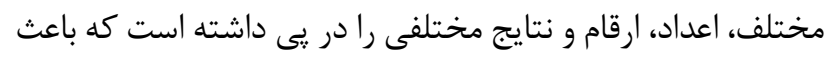

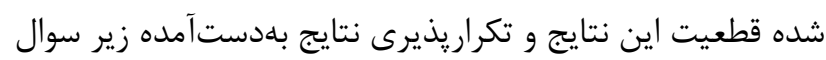

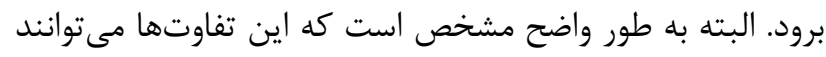

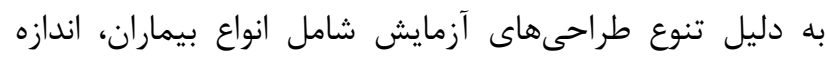

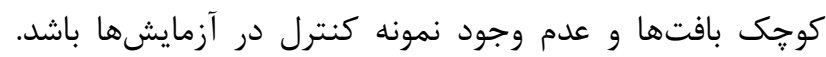

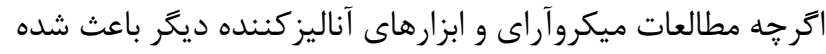

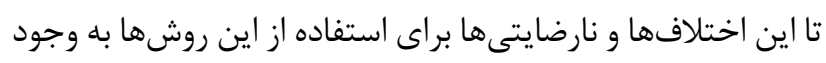

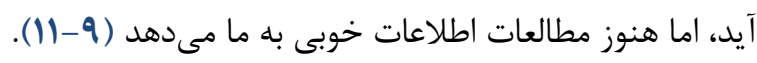
ماكروفازهايى كه به صورت كلاسيك يا آلترناتيو فعال

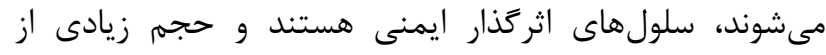

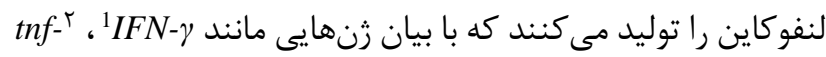

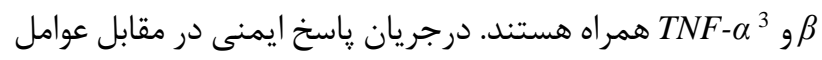

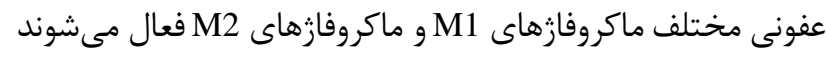

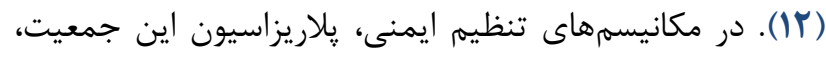

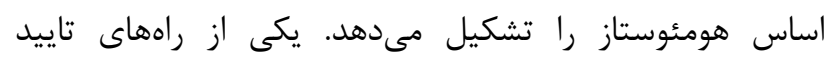
يلاريزاسيون، بيان سايتوكاينهاى هو

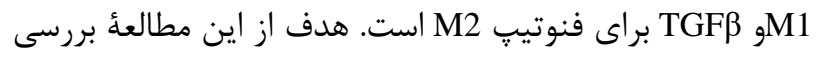
تاثير سالمونلا تيفى بر فعاليت منوسيتهاى شبه ماكروفاز خون

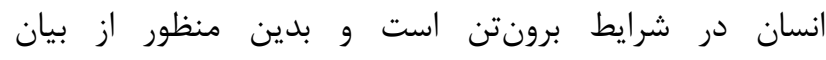

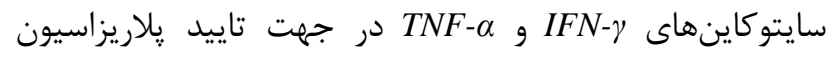

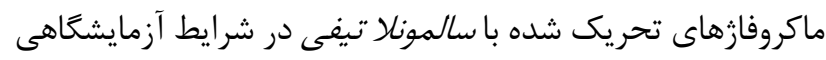

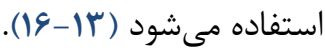

اولين موانعى است كه سالمونلا با آن روبروست و لايه ضخيمى از مخاط است كه سطح إيتليوم روده را مى يوشاند و يكى مانع اوليه

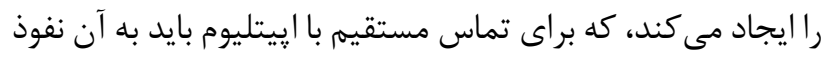
كرد. از ديخر موانع مىتوان به سلولهاى ماندان ماكروفاز اشاره كرد.

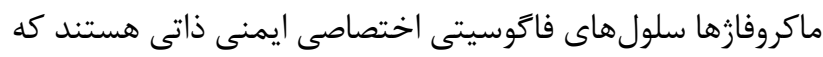

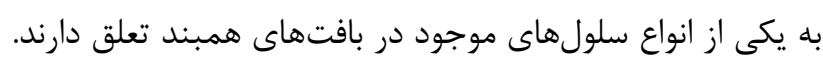

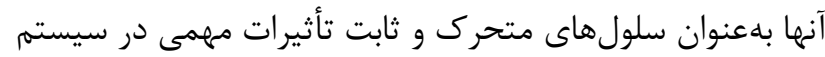

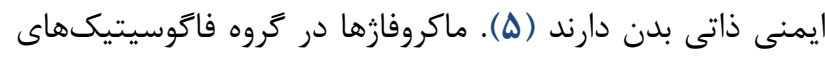

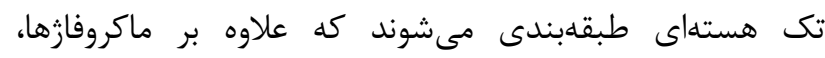

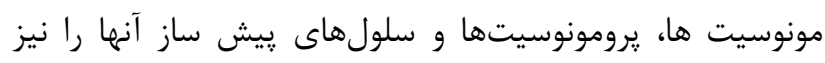
شامل مىشود. عملكرد اصلى سلولهاى متعلق به اين سيستم

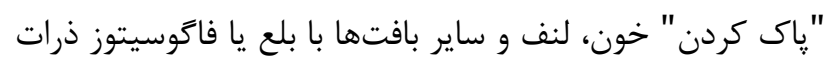

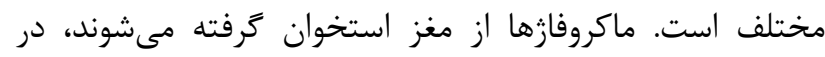

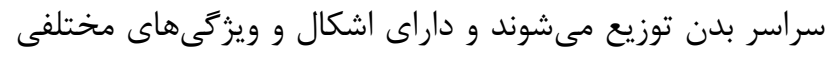

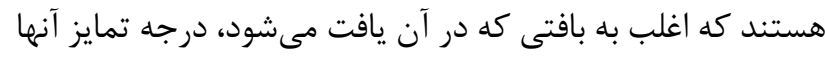

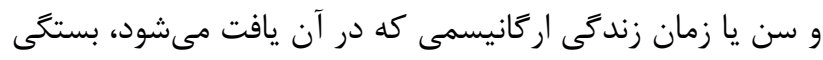

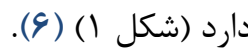
طى حند سال كذشته آناليز تغييرات بيان mRNA ها، در بسيارى از مطالعات مورد كاوش و تحقيق قرار كَرفته است. بسيارى لئان

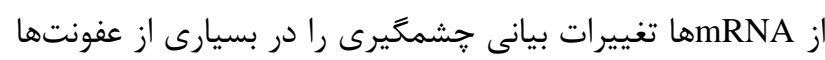

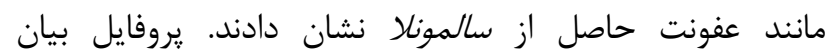
ها كوياى اين قضيه هستند كه مى توان از تغييرات بيان

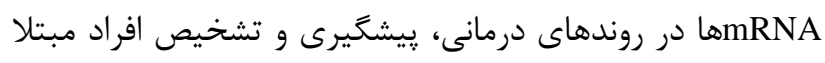

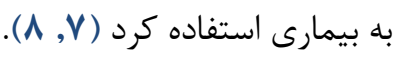

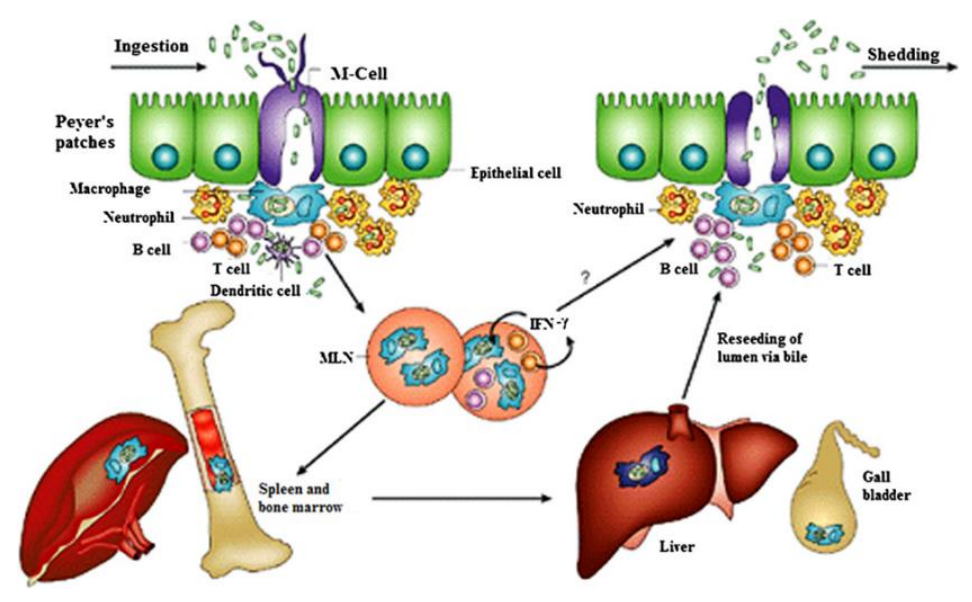

شكل ا. شماتيكى از تعاملات و واكنشهاى سلولهاى ايمنى در عفونت سالمونلا تيفى (f).

${ }^{3}$ Tumor necrosis factor alpha
${ }^{1}$ Interferon gamma
${ }^{2}$ Tumor necrosis factor beta 
جداسازى سلولهاى تكهستهاى خون محيطى peripheral blood mononuclear cell (PBMC) ابتدا ها سىسى خون وريدى تازه حاوى هيارين از يك داوطلب سالم تهيه شد. سبس در شرايط استريل و زير هود به

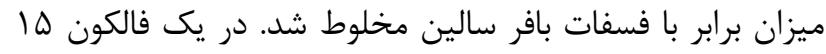
سىسى به اندازه ه ميلى ليتر فايكول (Inno-train, Germany) و سيس ه ميلىليتر خون مخلوط شده با فسفات بافر سالين اضافه

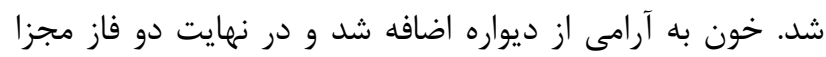

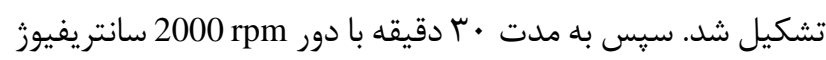
شد. بعد از سانتر يفيوز هاله سفيد رنغ و ابرى در وسط شكل كرفت

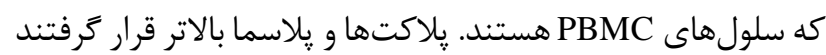

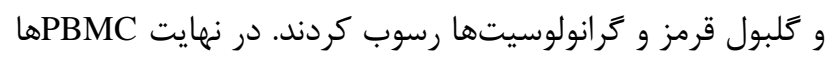
با پييتِ ياستور به ارامى برداشته شدند و با ترييان بلو شمارش و و

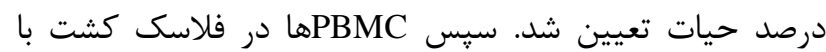

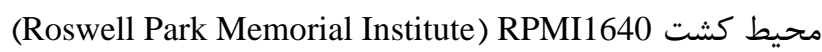
(Gibco, USA) (Foetal Bovine Serum) FBS, (Gibco, USA) به مقدار • ل درصد و در نهايت آنتىبيوتيك ين استرٍ إنا درصد

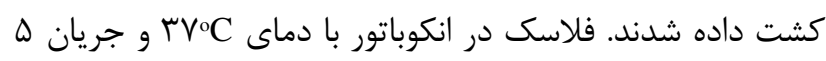

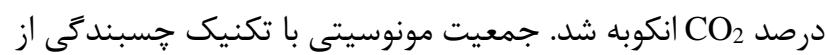
سلولهاى شناور در محيط كامل كشت سلول تفكيك شد. سلولهاى تك هستهاى به بستر كشت متصل و به سلولهاى

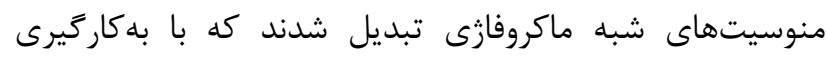

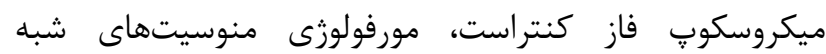

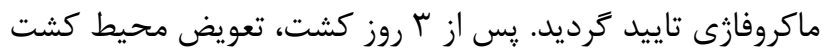
صورت كرفت و سيس سلولها در سه فلاسك به طور جداكانهانه

ياساز داده شدند و هر فلاسك تحت تيمار قرار كرفت (1) (1). لازم به ذكر است كه غلظت محركهاى مورد تيمار با

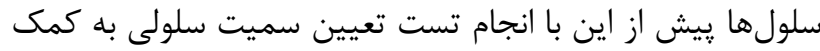

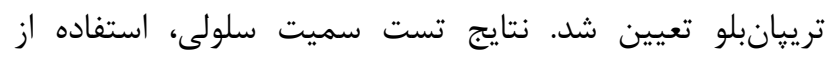
غلظتهاى سالمونلا تيفى را براى تيمار در محبط كشت مجاز نشان تُان داد كه از غلظت 4>103 cfu/ml استفاده شد. انكوباسيون در

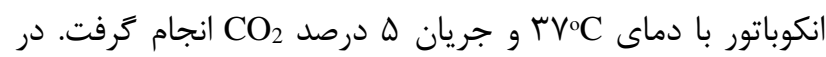

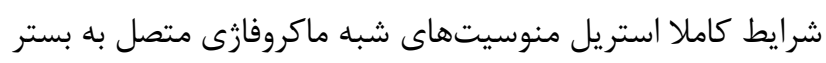

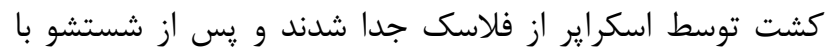

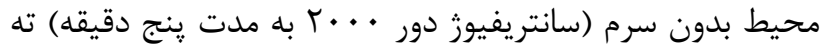

مواد و روشها

اين يزوهش مقطعى-توصيفى با كد اخلاق

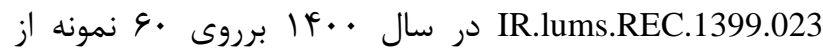

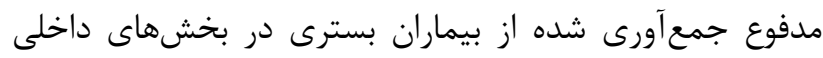

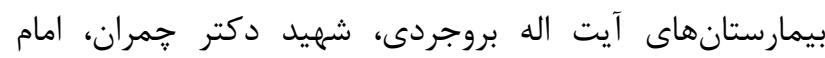

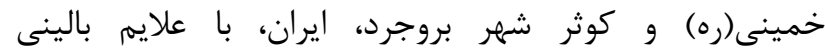
كاستروآنتريت، به منظون ونظور جداسازى سويه سالمونا تيفى انجام كرديد. لازم به ذكر است كه به افراد داوطلب توضيحات اجمالى دني توسط متخصص ارائه شده و موافقت كتبى براى دريافت نمونه و

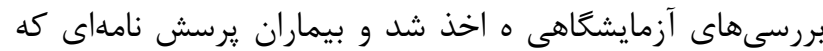

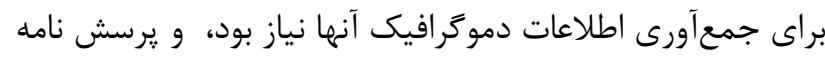
تكميل گرديد. در اين مطالعه افرادى كه موافقتنامه كتبى را المضاع

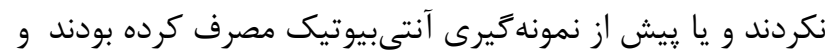

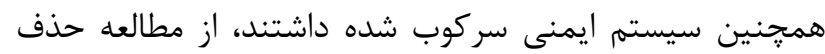

شدند.

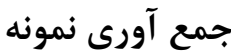

نمونه مدفوع در ظرف يلاستيكى تميز، دهان گشاد با دريوش

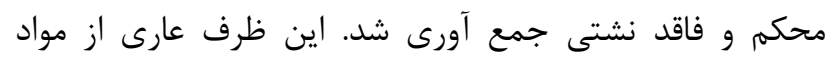

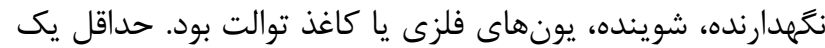
كرم مدفوع با قوام طبيعى (به اندازه يك فندق) يا ها ميلى ليتر

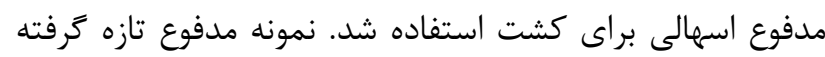
شد و در مدت ·ـ دقيقه و حداكثر r ساعت بعد از نمونه كيرى

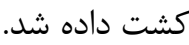

مردان و زنانى در اين مطالعه وارد شدند كه علائم مربوط به

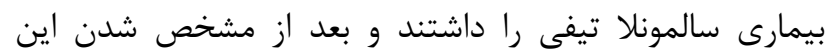

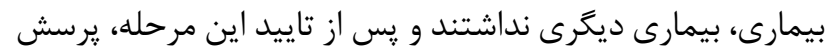

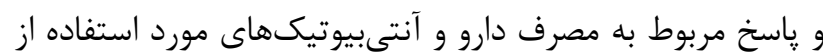

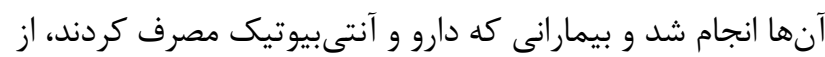
مطالعه خارج شدند.

\section{جداسازى و تشخيص سالمونلا}

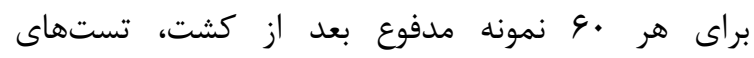

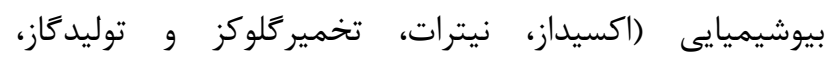

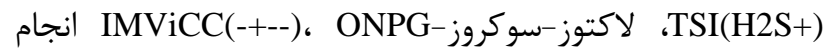
شد. نمونه استاندارد سالمونلا تيفى ATCC14028 بهعنوان كنترل از مركز يزوهشهاى علمى-صنعتى ايران تهيه شد (IV). 
ماكروليتر RNAse inhibitor و در نهايت هـ/•• ماكروليتر آنزيم

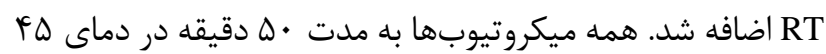
درجه سلسيوس در دستخاه PCR انكوبه شدند.

\section{بر رسى بيان زنهاى IFN-p ، TNF-}

رeal Time PCR زن رفرانس با استفاده از تكنيك

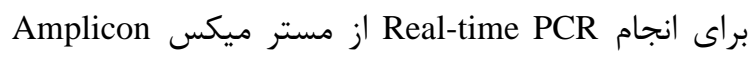

استفاده شده است و رنخ مورد استفاده در اين مستر ميكس امس

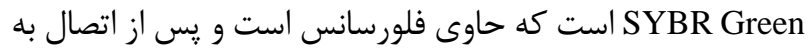

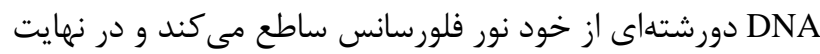

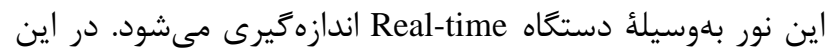
واكنشها، cDNA template ساخته شده در مراحل قبل بود.

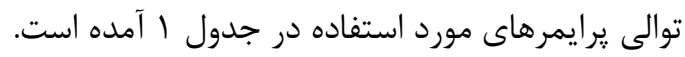

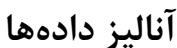

تمام دادهاى حاصل از Real Time كه به صورت Ct است با استفاده از برنامه Excel و Graphpad prism مورد آناليز و در انتها لتاديا

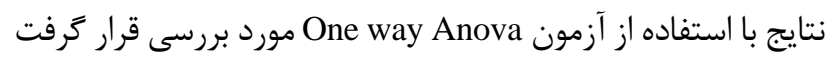
و نتايج آمارى كمتر از ه • • • مورد قبول و معنادار تلقى شده است.
نشين سلولى براى انجام تمهيدات بررسى بيان زن در مرحله بعدى

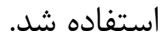

استخراج RNA با ترايزول

TRIzolTM براى استخراج RNA فلاسك از ترايزول Thermo ) alog Numbers اسىسى Cat Reagent استفاده شد. علاوه بر اين براى جلو كيرى (Fisher Scientific, Inc. از آلودَى DNA و حذف RNA استخراج شده توسط آنزيم RNase و RNase/ DNase free ازيكروتيوبهاى (Yekta Tajhiz, Iran) سرسميلرهاى فيلتردار و آب عارى از نوكلئاز استفاده شد.

\section{ساخت cDNA}

كيت مورد استفاده براى سنتز CDNA، Taiwan) Smobio بود. مراحل سنتز طبق دستورالعمل كيت انجام شد. از هر نمونه

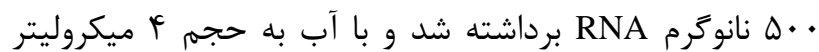

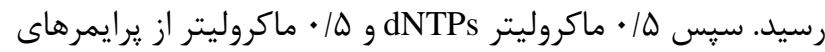
Random hexamer O Oligo dt

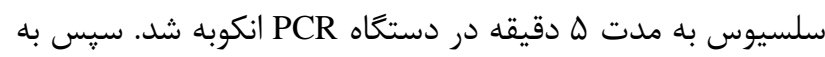
هر ميكروتيوب r ميكروليتر DTT، r ميكروليتر آب DEPC، فا •

جدول ا. يرايمرهاى زنها براى Real time PCR

\begin{tabular}{|c|c|c|}
\hline نام برايمر & 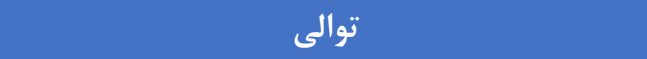 & وزن مولكولى محصول \\
\hline IFN- $\gamma \mathrm{F}$ & TTGGGTTCTCTTGGCTGTTA & \multirow{2}{*}{ 151bp } \\
\hline IFN- $\gamma \mathrm{R}$ & TTCTGTCACTCTCCTCCTCCA & \\
\hline TNF- $\alpha \mathrm{F}$ & TTGGGTTCTCTTGGCTGTTA & \multirow{2}{*}{$251 b p$} \\
\hline $\mathrm{TNF}-\alpha \mathrm{R}$ & TTCTGTCACTCTCCTCCTCCA & \\
\hline GAPDH-F & TGCTGTCTCCCTGTTTGATGTATCT & \multirow{2}{*}{$86 \mathrm{bp}$} \\
\hline GAPDH-R & TCTCTGCTCCCCACCTCTAAGT & \\
\hline
\end{tabular}

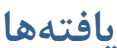

ميان نمونهاى جمعآورى شده، •9 نمونه كشت مثبت سالمونلا

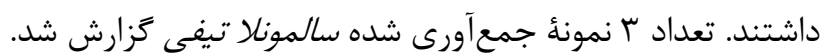

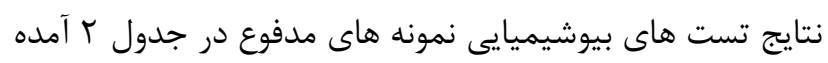

نتايج جمع آورى نمونهها

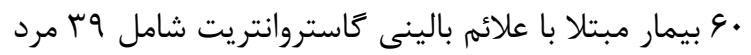

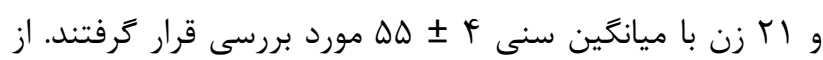


جدول r. نتايج تستهاى بيوشيميايى نمونههاى مدفوع

\begin{tabular}{|c|ccccccccccc|c|} 
organism & $\mathrm{kIA}$ & $\mathrm{H}_{2} \mathrm{~S}$ & Gas & $\mathrm{MR}$ & $\mathrm{VP}$ & citrate & LDC & Urease & Arabinose & $\begin{array}{c}\text { Ornitin } \\
\text { decarboxylase }\end{array}$ & Rhamnose & Trehalose \\
$\begin{array}{c}\text { Genus: } \\
\text { Salmonella } \\
\text {.Typhi }\end{array}$ & $A L K / A$ & + & - & + & - & - & + & - & - & - & - & + \\
\hline
\end{tabular}

\section{بررسى تكثير اختصاصى محصولات Real time PCR}

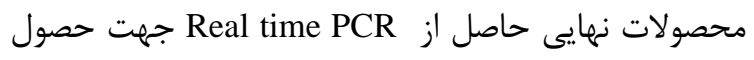

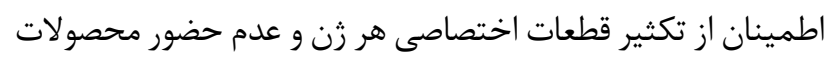

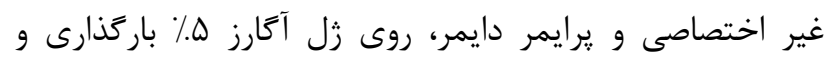
الكتروفورز شد. علاوه بر اين از منحنى ذوب دوب نيز استفاده شد (شكل

\section{نتايج اختصاصيت و حساسيت يرايمرها}

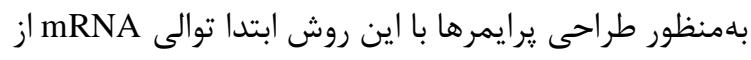

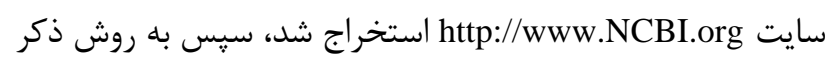

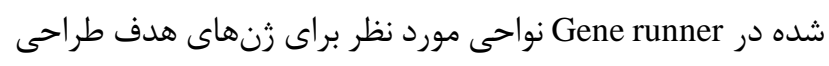
كرديد و در نهايت در سايت BLAST نواحى به طور اختصاصى درد تاييد كرديد.
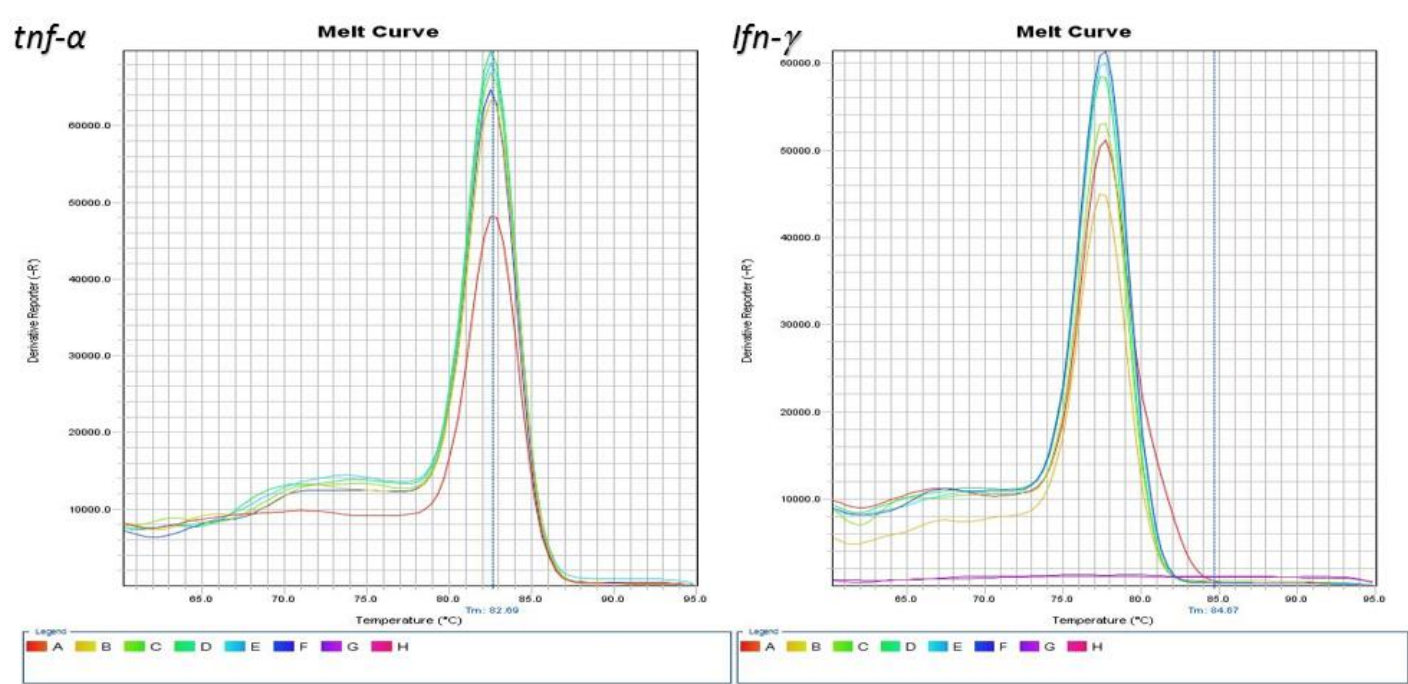

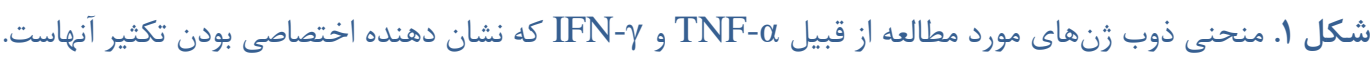

هاى تيمارشده با سويأ پاتوزن و سويه ى ATBMC

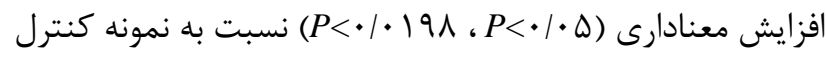

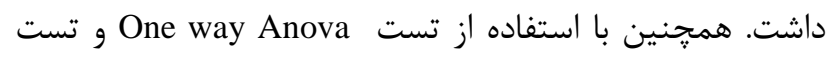
مقايسه اى Sukey's multiple comparisons test يكديخر مقايسه شدند و معنادارى هر كدام در جدول ب آمده است. افزايش بيان زن TNFATCC 14028

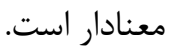

نتايج بيان ثن TNF-

ميزان بيان كمى زن كشت سلول رشد كرده در محيط حاوى سالمونلا تيفى و سويئ

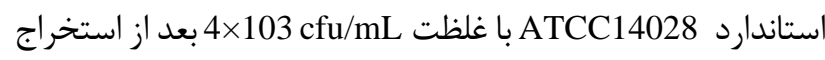

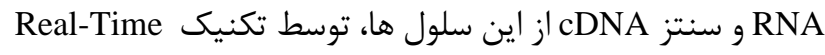

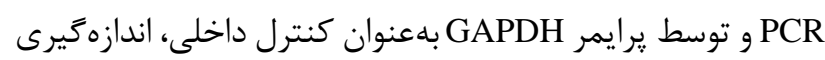
شد. نتايج نشان داد تغييرات نسبى بيان زن 
جدول r. مقايسه بيان زن

\begin{tabular}{|cccc|}
\hline Tukey's multiple comparisons test & Mean Diff. & 95\% CI of diff. & Significant? \\
\hline Control vs. ATCC & -0.4589 & -1.948 to 1.030 & No \\
\hline Control vs. Pathogen & -1.875 & -3.364 to -0.3861 & Yes \\
\hline ATCC vs. Pathogen & -1.416 & -2.905 to 0.07280 & No \\
\hline
\end{tabular}

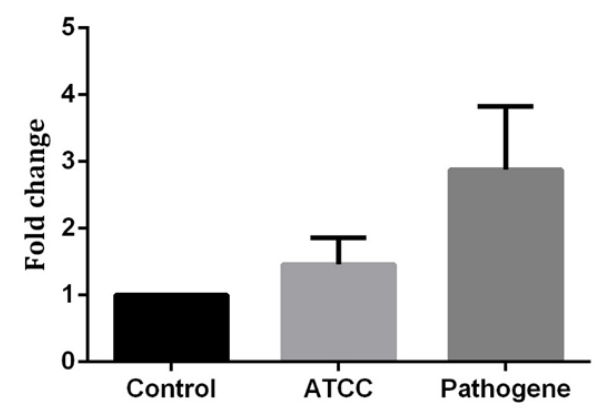

شكل r. تغييرات بيان رن TNFATCC

جدول F. جدول بيان جند برابرى زن

\begin{tabular}{|cc|}
\hline نو نو نمونه & Fold Change \\
\hline control & 1 \\
\hline ATTC & 1.45 \\
\hline Pathogen & 2.87 \\
\hline
\end{tabular}

نتايج كمى حاصل از تغييرات بيان زن TNF-

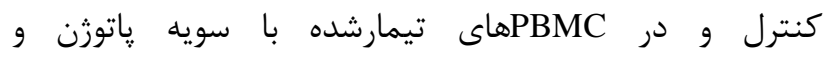

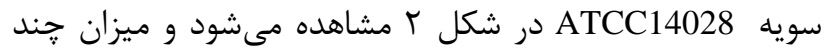
برابرى اين زن (فولد) در هر نمونه در جدول f آمده است.

\section{IFN-ק نتايج بيان زن}

ميزان بيان كمى زن IFN- در نمونه كنترل، نمونه تيمار

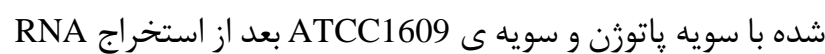
و سنتز cDNA از اين سلول ها، توسط تكنيك Real time PCR

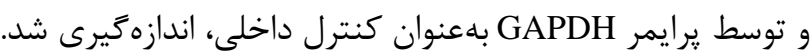

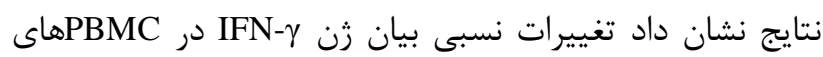

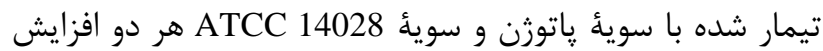

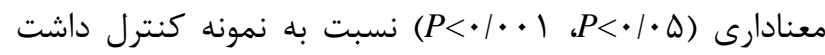

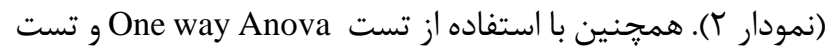
مقايسه اي Tukey's multiple comparisons test يكديكر مقايسه شدند و معنادارى هر كدام در زير آمده است

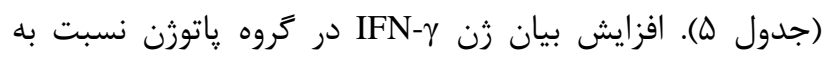

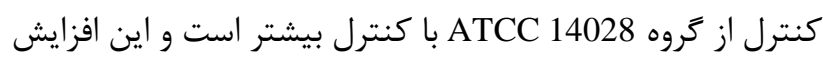

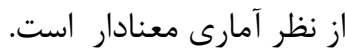

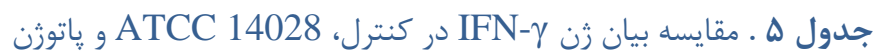

\begin{tabular}{|cccc|}
\hline Tukey's multiple comparisons test & Mean Diff. & $\mathbf{9 5 \%}$ CI of diff. & Significant? \\
\hline Control vs. ATCC 14028 & -0.1777 & -1.103 to 0.7475 & No \\
\hline Control vs. pathogen & -2.010 & -2.935 to -1.084 & Yes \\
\hline ATCC vs. pathogen & -1.832 & -2.757 to -0.9067 & Yes \\
\hline
\end{tabular}

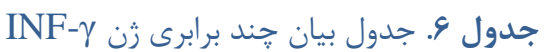

\begin{tabular}{|cc|}
\hline نوع نمونه & Fold Change \\
\hline control & 1 \\
\hline ATCC 14028 & 1.17 \\
\hline Pathogen & $r$ \\
\hline
\end{tabular}

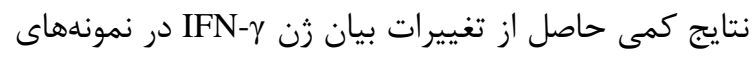
كنترل و در PBMC هاى تحت سوية ياتوزن و سويه ى ATCC

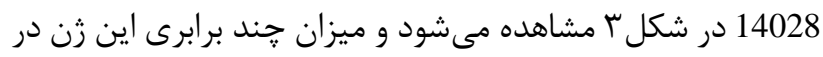
هر نمونه در جدول 9 آمده است. 
ماكروفازها را بهعنوان M1 يا M2 ييشنهاد كردند. اين اصطلاحات

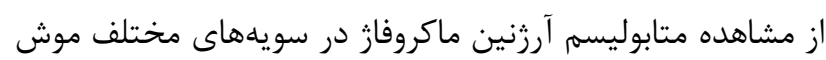

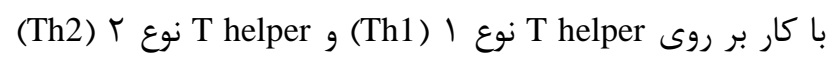

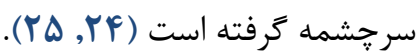

Th1 با سلولهاى Th كه بيشتر IFN- توليد مى كنند، فعال

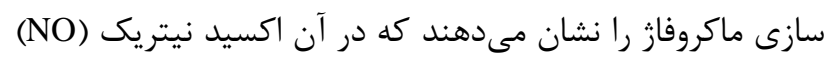

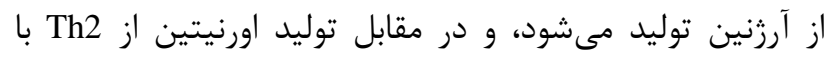

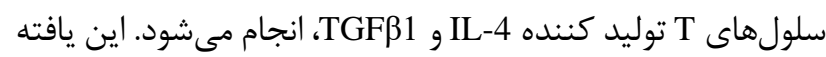

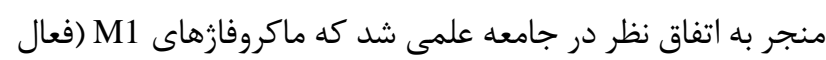

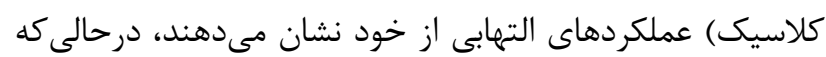

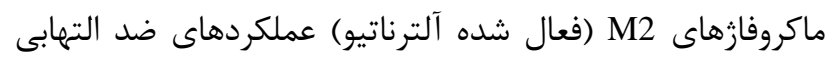

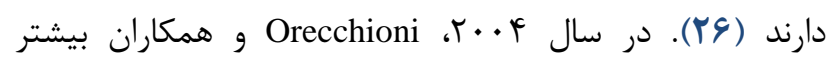

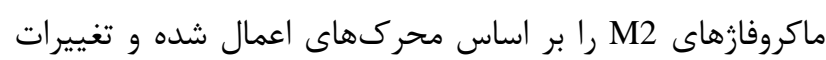

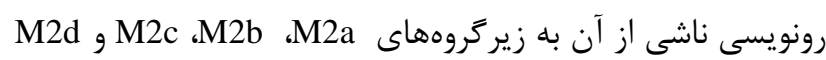

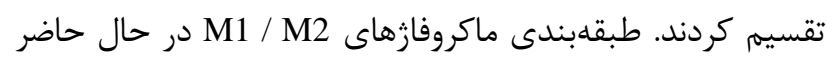
يك روش كاملا ساده در نظر كرفته شده است كه طيف طيف جمعيت ماكروفازها را به اندازه كافى توصيف نمى كند (YV)

بهنوان مثال، شناسايى ماكروفازهاى مرتبط با تومور

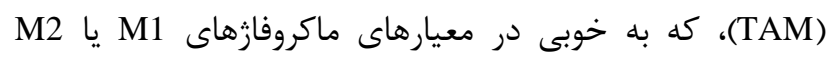

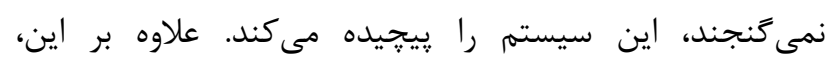

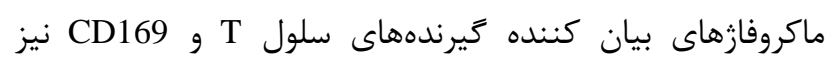

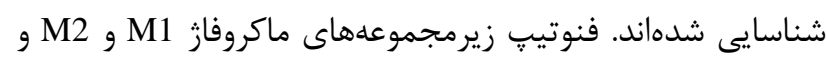

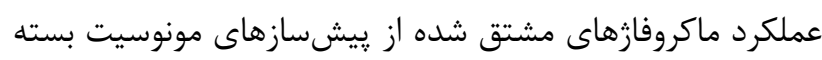

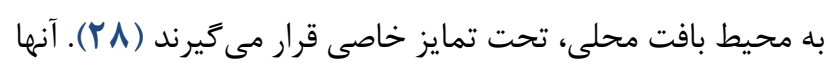

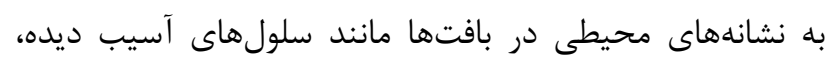

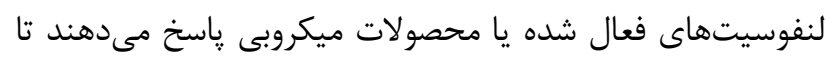

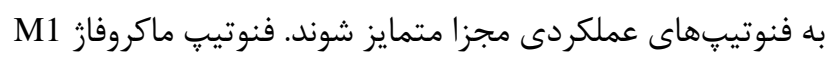
با توليد سطوح بالاى سيتوكينهاى يُ بيش التهابى، توانايى ايجاد

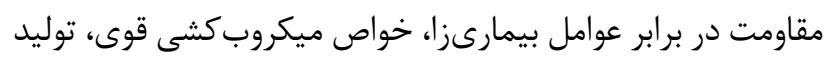

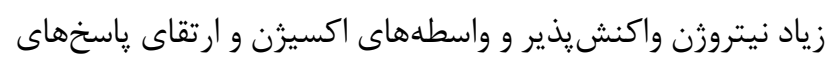

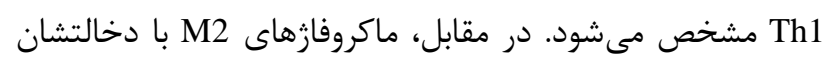

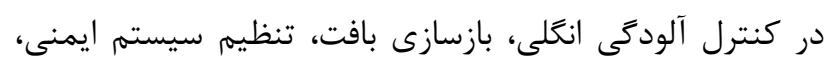

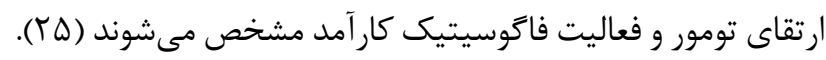

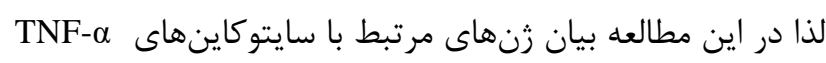
IFN-

LPS اينترفرون گاما و فاكتور محرك كلنى كرانولوسيت

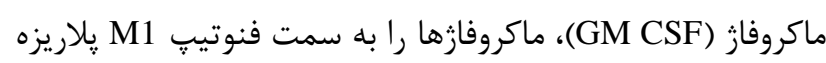

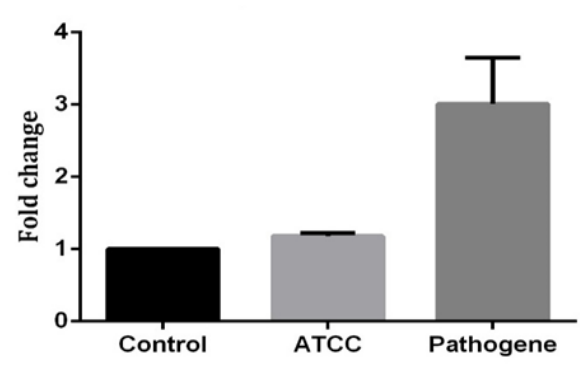

$$
\text { شكل r. تغييرات بيان زن ATCC و ياتورن IFN در سويههاى كنترل، }
$$

بحث

مطالعات نشان داده است كه پيشرفت بيمارىها در افراد با

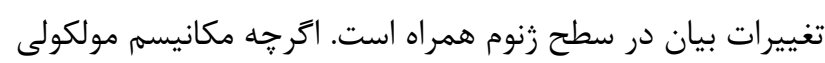

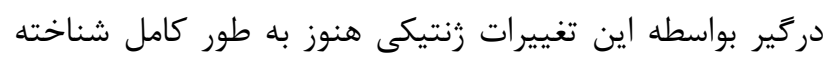

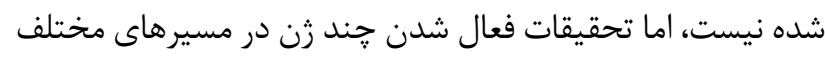

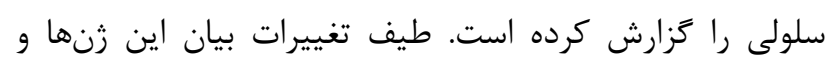

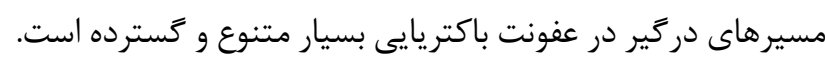

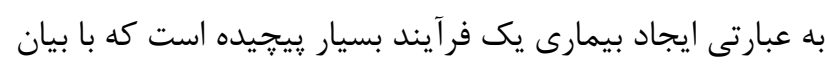

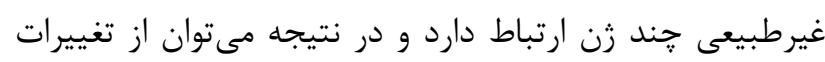

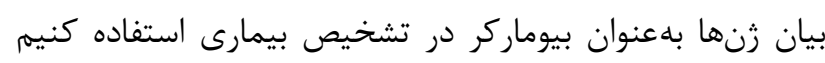

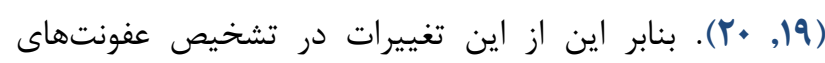

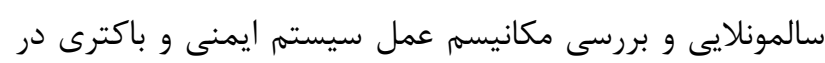
برابر يكديخر نيز مىتوان استفاده كرد.

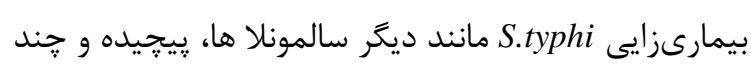

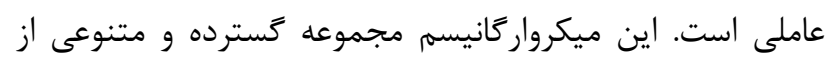

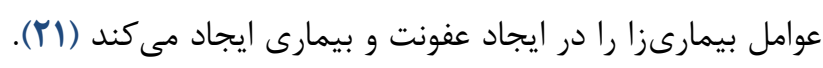

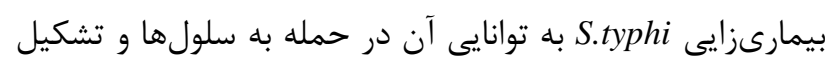

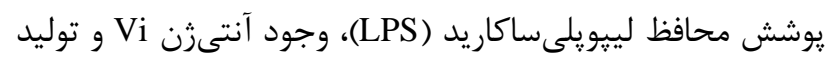

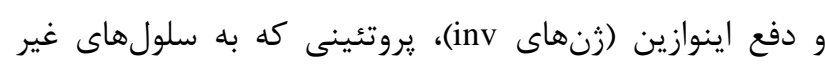

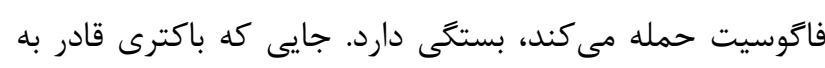

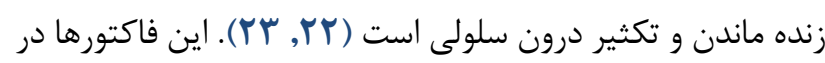
ميزبان، باعث واكنشهاى سيستم ايمنى مى شود. در دهه • • 199 كشف شد كه Cytokine Interleukin-4 اثرات

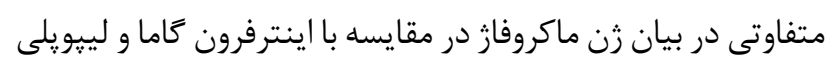

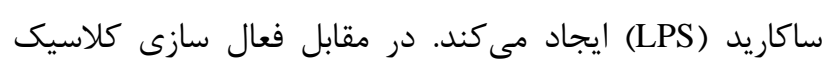

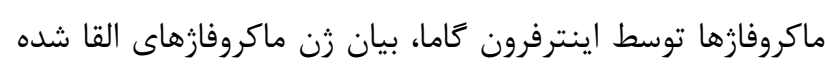

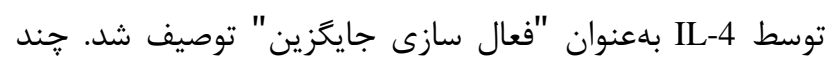

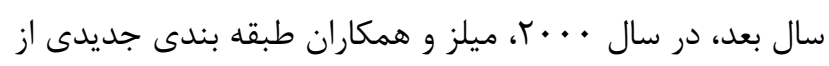


داده شده است كه در شرايط آزمايشًاهى، ماكروفازها قادر به

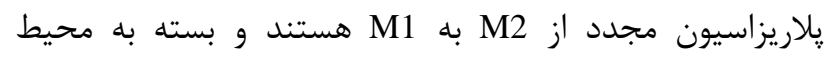
كموكاين مىتوانند يلاريزاسيون را معكوس كنند.

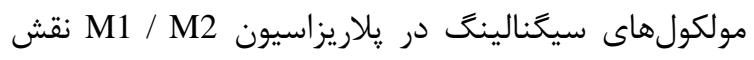

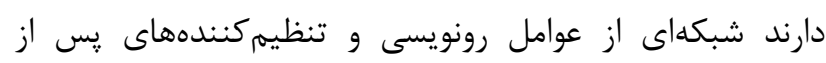

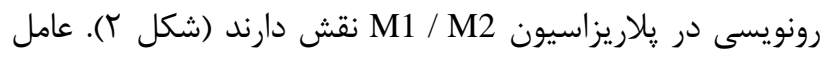

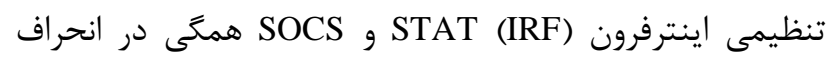

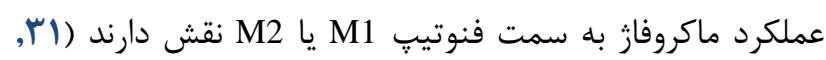

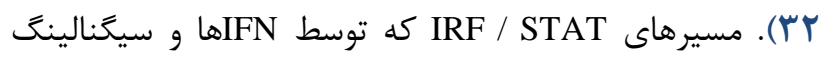
فعال مىشوند، ماكروفازها را از طريق SLR

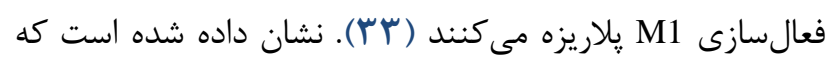

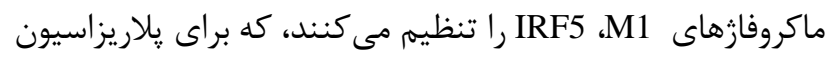

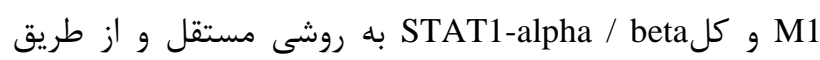
MyD88 در پيلاريزاسيون M1 نقش دارد (YV).
مى كنند، كه باعث ترشح مقدار زيادى سيتوكين مانند

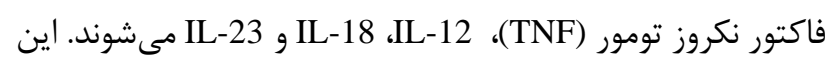

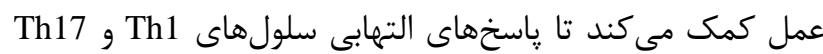

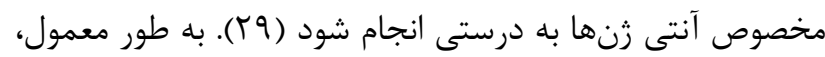

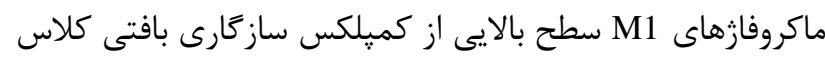

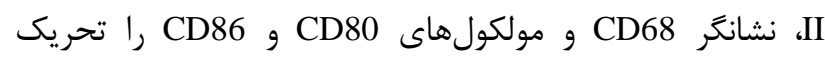

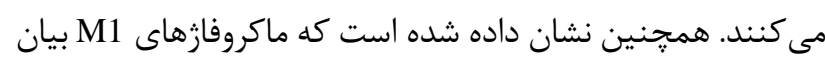

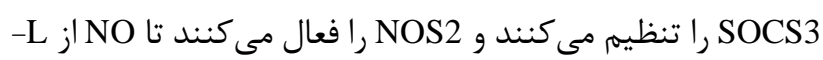

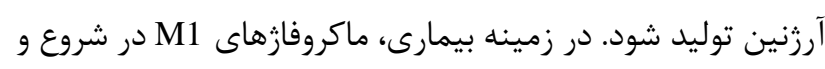

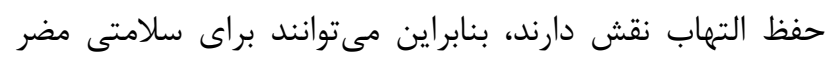

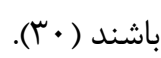

ماكروفازهاى M1 و M2 داراى يروفايلهاى كيرنده كموكاين

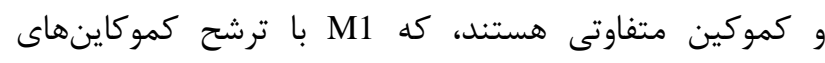

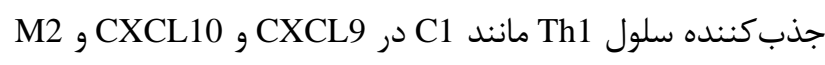
با ترشح CCL17، CL22 و CL24 عمل مكى كند. اخيراً نشان

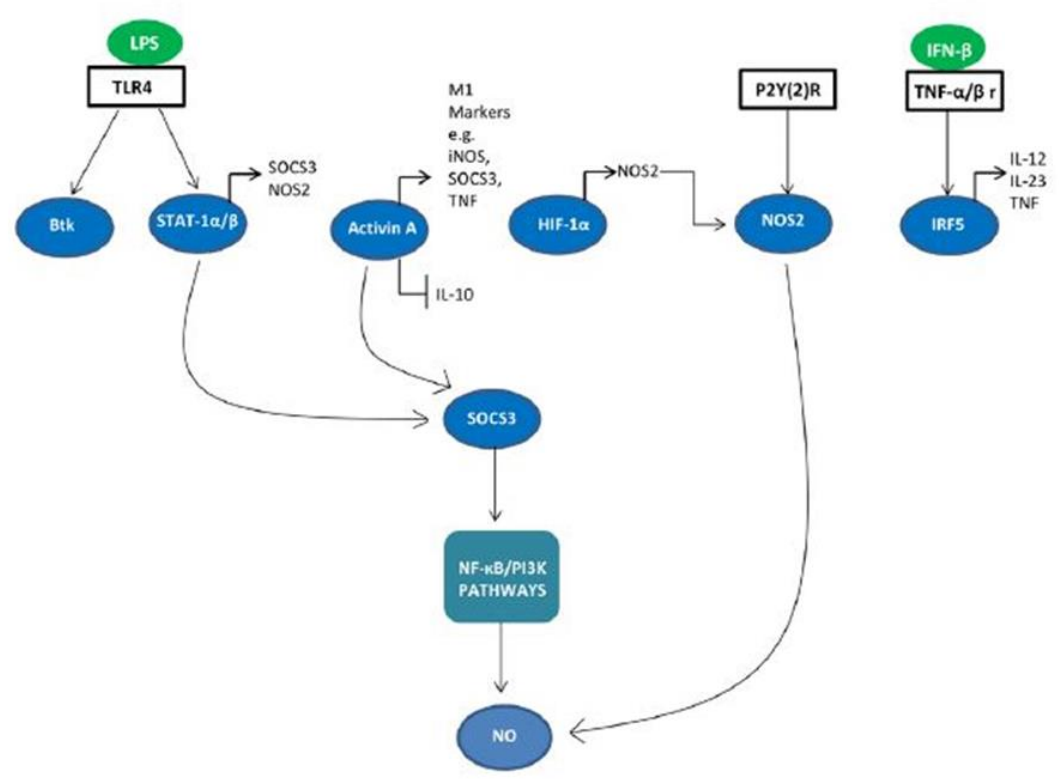

M1 شكل r. مولكولهاى سيخنالينَ دركير در يلاريزاسيون

دادند، اين افزايش بيان در سوئٔ بالينى سالمونلا تيفى معنادار بوده و نسبت به سويه استاندارد نيز بيشتر بوده است.

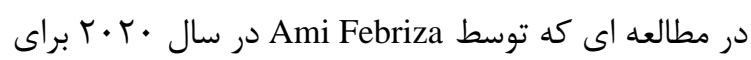

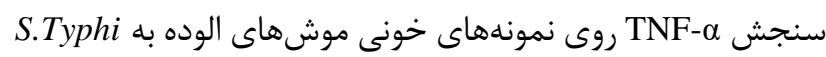

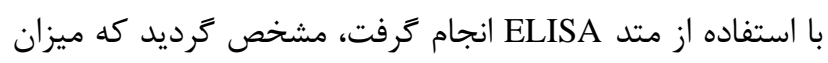
TNF- $\alpha$
در مطالعه حاضر، بيان زن سايتو كاينهاى IFN- I و

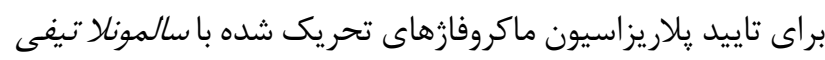
در شرايط آزمايشگاهى در دو سويه استاندارد سالمونلا و سورئئ

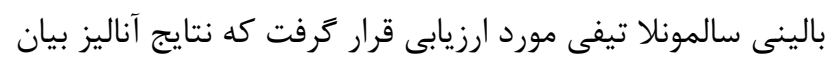

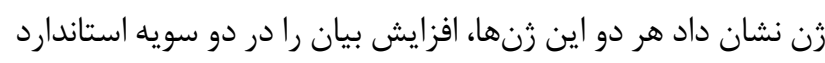

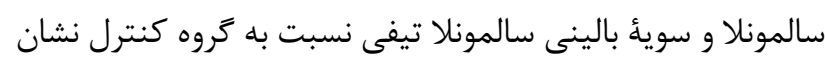




$$
\text { نتيجه گيبرى }
$$

بيان افزايش يافته IFN- و و TNF-

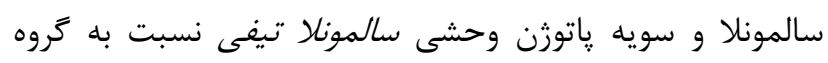

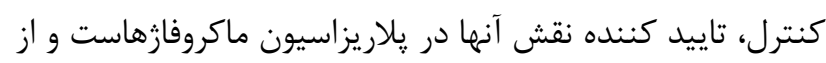

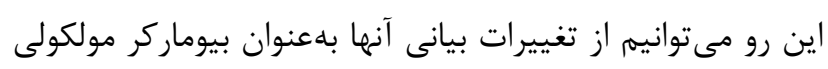
در تشخيص عفونتهاى مربوط به سالمونلا استفاده كنيم. رئه

$$
\text { سياسگزارى }
$$

بضمن تشكر از تمام دوستانى كه ما را در مراحل مختلف اين

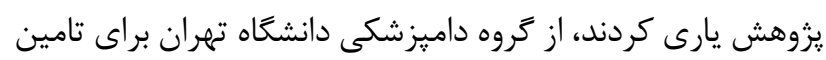

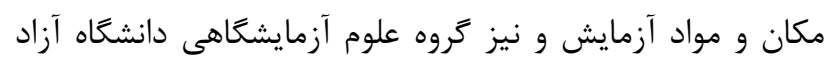

$$
\text { اسلامى واحد بروجرد تقدير مىشود. }
$$

$$
\text { تعارض در منافع }
$$

بين نويسندكان تعارض در منافع كزاش نشده است.

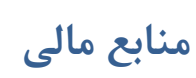

اين مقاله بركَفته از يايان نامه مقطع دكترى تخصصى (Ph.D)

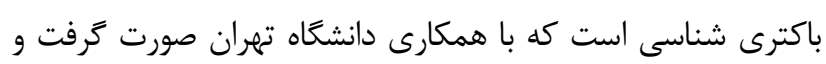

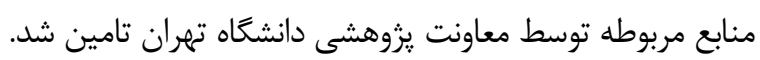

آنتىبيوتيك منجر به كاهش آن مى

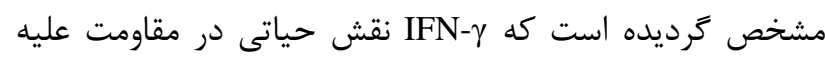
عفونت S.Typhi با افزايش فعاليت ضدباكتريايى ماكروفازها ايفا

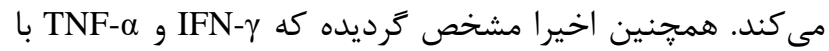

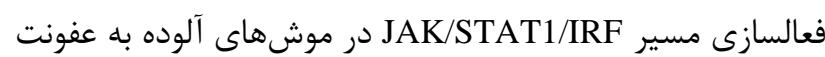

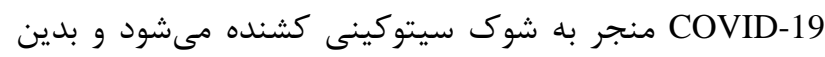
دليل استفاده از آنتىبادىهاى خنثى كننده عليه اين دو، مى تواند

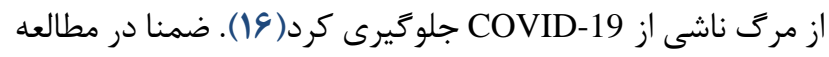

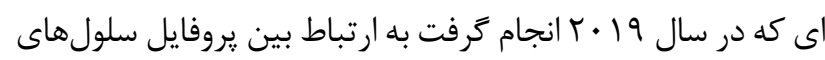

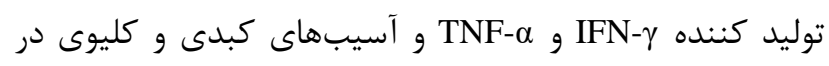

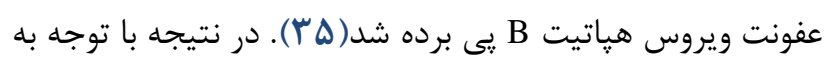

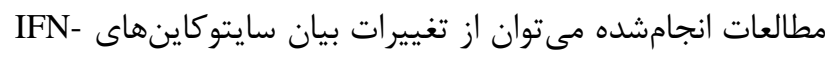
TNF- $\gamma$ و

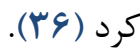

البته اين نكته قابل ذكر است كه با توجه به مطالب كَفته

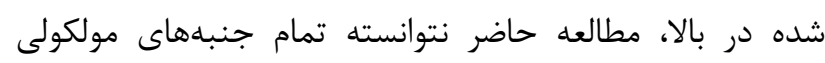

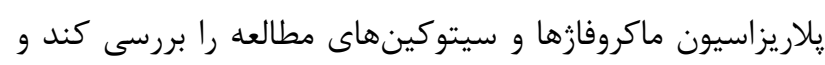

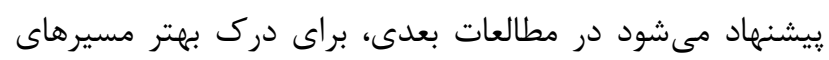

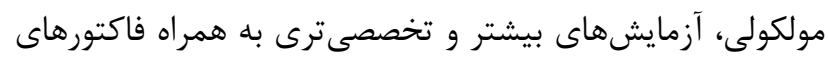
بيشتر بررسى كردد أمايش 